\title{
NORTHERN PURGATIVES, SOUTHERN RESTORATIVES: MING MEDICAL REGIONALISM
}

\author{
Marta E. Hanson
}

\begin{abstract}
Physicians during the Ming dynasty (1368-1644) understood that the Chinese empire was geographically diverse. They observed that their patients were corporeally and physiologically heterogeneous. They interpreted this ecological and human diversity within the reunited Ming Empire according to both an ancient northwest-southeast axis and a new emphasis on north versus south. The geographic distinctions - northern and southern (nanbei 南北) as well as northwestern (xibei西北) and southeastern (dongnan 東南)-similarly helped explain doctrinal and therapeutic divergences within the literate sector of Chinese medicine. They thought about ecological, climatic, and human variation within the framework of a uniquely Chinese northwestsoutheast polarity with roots in Chinese mythology and the Inner Canon of the Yellow Emperor. They also thought in terms of a north-ern and southern split in medicine, which the Yuan scholar Dai Liang 戴良(1317-1383) explicitly mentioned in his writings. The Ming physicians who discussed medical regionalism mostly asserted, however, the opposite; namely their own impartiality as medical authorities for all of China. Nevertheless, their essays on regionalism reveal considerable tensions, fissures, and conflicts in the literate sector of Ming medicine.
\end{abstract}

\section{Introduction}

With the unprecedented expansion of medical publishing during the Ming dynasty (1368-1644), currents of medical thought primarily developed in northern China circulated extensively for the first time throughout the increasingly wealthy and urbanised Jiangnan region of central China.' These Ming medical texts made possible the widespread distribution of a common frame of reference regarding regional styles of practice based in both the medical canons from Han antiquity and post-northern-Song (960-1126) revisionist writings from the

' On the publishing boom in the Ming, see Brokaw and Chow 2005. For a study of one late-Ming publisher who also published medical texts, see Widmer 1996, pp. 77-122.

(C) Brill, Leiden, 2006

ASME 2,2 
Jin (1115-1234) and Yuan dynasties (1280-1368)..$^{2}$ In the process of coming to terms with the medical innovations of the Jin-Yuan period by transmitting them from the north to the south, the mid- to late-Ming physicians-Wang Lun 王綸 (fl. 1484-1521), Xue Ji 薛己(1487-1559), Xu Chunfu 徐春甫 (1520?-1596?), and Li Zhongzi 李中梓 (15881655)-discussed regional differences in climates, constitutions, diseases, and treatments. They reassessed inherited medical knowledge through their regional lens. Instead of a unified medical orthodoxy passed on from northern-Song medical activism, ${ }^{3}$ they encountered doctrinal conflict and therapeutic diversity.

Two main concepts borrowed from the sociology of knowledge and from anthropology guide this interpretation. First, medical discourse is often as much about social ills as it is about physical illness. Diagnosing disease may also serve as a means for making a social diagnosis. Second, polarities are not symmetrical but asymmetric, hierarchical, and unequal. One pole is always given higher value. Polarities directly reflect value judgments about the ideal social order. In the Chinese yin-yang polarity related to medical regionalism, north is respected over south; strong is admired over weak; frugality is favoured over indulgence. Disease as social diagnosis and the value-laded asymmetry of yin-yang polarities weave together a culturally and historically situated analysis of Ming medical regionalism.

My interest in Ming medical regionalism stems from previous research on the role medical regionalism and Jiangnan regional identity played (or did not) in the formation of two new currents of learning that emerged during the Qing dynasty focused on epidemics (wenyi xuepai 瘟疫學派) and on warm or febrile disorders (wenbing xue pai 溫病學派). ${ }^{4}$ In this article, I analyse the Ming debates on regional variation in the literate sector of classical Chinese medicine to establish the range of issues, concepts, and practices related to medical regionalism that later Qing physicians then drew upon for their own purposes. ${ }^{5}$ Other scholars have written extensively about Chinese

${ }^{2}$ Leung 2003a, pp. 374-98. For Song medicine, Hinrichs 2004.

${ }^{3}$ On northern-Song medical activism in terms of expansion of medical education, medical institutions, medical publishing, and drug therapy as well as the standardization of acu-moxa therapy and texts, see Goldschmidt 2005. On the particular role of Emperor Huizong (1082-1135, r. 1101-1126), see Goldschmidt 2006.

${ }^{4}$ Hanson 1997, 1998.

${ }^{5}$ For convincing arguments that support revising Kleinman's model of the three sectors of health care from the 'professional sector' to the 'literate sector' for early-modern China, see Cullen 1993. Original Three Sectors model explained in Kleinman 1980. 
conceptions of the relationship between local environment and illness before the Qing dynasty. ${ }^{6}$

In contrast to these diachronic studies, I take a more synchronic approach. This essay illuminates changes over time just during the second half of the Ming dynasty and focuses on how Ming physicians used this relationship at particular historical junctures over that period to discuss other matters that concerned them, both within the medical sphere and more broadly within society.

Physicians wrote about diseases not simply to explain or to treat them, but also as an index of problems in society and a critical commentary on them. ${ }^{7}$ The case records of the Ming physician Wang $\mathrm{Ji}$ 汪機 (1463-1539) are best read with an eye to broader social and economic transformations in early sixteenth-century Anhui when and where he lived. His diagnosis of depletion disorders among many of his male patients due to overindulgence in sex, drinking wine, and eating rich foods, for example, mirrored his own anxiety about the newly emergent merchant class and the declining morals in contemporary Huizhou. ${ }^{8}$ Late-Ming male physicians' criticism of 'medical grannies' ( $y i p o$ 醫婆 and yifu 醫婦) do not reflect the lower status and poorer quality of illiterate female healers, but rather express their anxiety about female healers as competitors, especially for the care of women and children. ${ }^{9}$ Similar tensions between male and female healers come to play in the narrative of the sixteenthcentury novel The Plum in the Golden Vase (Jinpingmei 金瓶梅)..$^{10}$ Ming medical regionalism reveals comparable anxieties over competition and a range of tensions, fissures, and conflicts in the social and cultural geography of literate Chinese medicine."

${ }^{6}$ Xiao Fan 1993, pp. 67-171; Fan Ka Wai 1995, pp. 155-77; Fan Ka Wai 2004, pp. 127-54; Sun Tiansheng 1998, pp. 68-74; and Leung 2002, pp. 165-212.

7 Rosenberg 1992, p. xxii. Two essays in this volume directly deal with the use of 'disease as social diagnosis' in the history of what is called 'social medicine' in Western medical history: Eyler 1992, pp. 275-96; Fee 1992, pp. 297-317. He similarly used the nineteenth-century cholera epidemics as a sampling device to examine issues beyond medical practice, such as 'demographic and economic circumstances, ideas, and institutional relationships'. Rosenberg 1992a, pp. 109-21; Rosenberg 1962.

${ }^{8}$ Grant 2003, pp. 18-19.

${ }^{9}$ Furth 1999, pp. 266-300.

${ }^{10}$ Cullen 1993, pp. 99-150. Similar to Furth and Cullen, Pelling 1996 analyses the criticism of male practitioners towards female healers and their medical practices in early modern England as indications of the gender anxiety these men felt as physicians in a cultural sphere in which healing was gendered female.

"For a range of interpretations of the history of medical geography and medical 


\section{The asymmetry of polarities and value judgments}

The terms Ming physicians used to talk about the environment were not the modern ones such as 'environment' (huanjing 環境), 'district' (diyu 地域), or 'region' (quyu 區域), but rather were phrases that evoked the specific quality of localities such as 'local' (fangtu 方土), 'local climate' or 'local customs' (fengtu 風土), and 'land', 'soil', or 'the local god of the land' (tudi 土地). Sometimes physicians referred to broad regional categories such as 'south of the mountains' (Lingnan 嶺南) and 'south of the river' (Jiangnan 江南), provinces such as Shaanxi 陝西, Jiangsu 江蘇, or Zhejiang 浙江, or states in antiquity including Yan 燕, Wu 吳, or Yue 越. They also used three geographic models to divide the Chinese world into regions: the 'five regions' (wufang 五方), namely the center and the four cardinal directions, 'northwest-southeast' (dongnan-xibei 東南西北), and 'northern region-southern region' (beifangnanfang 北方南方). The specific terms they used illuminate how they imagined China's physical as well as political and social geography. The binaries they employed expressed value judgments on what physicians considered better and worse, not just for treating the patient but also for ameliorating society. ${ }^{12}$

By the mid-Ming dynasty, two comparable geographic binaries became the most important regional divisions in literate medical texts: northwest-southeast and north-south. Physicians used these binaries to systematise the correspondences they thought connected different climates, diseases, and bodily constitutions and required different therapeutic strategies in medical practice. Physicians also used these geo-cultural binaries to express problems they perceived both in the

discourses on the geography of health in European and colonial contexts, see the articles compiled in Rupke (ed.) 2000.

${ }_{12}$ For comparable binaries in ancient Indian medicine, see Zimmerman 1987, pp. 30-1. In ancient Indian medicine, for example, the central polarity in medical texts between the jāngala or jungle 'drylands' to the west and the anūpa 'marshlands' to the east expressed a preference for the jungle (and all things, foods, and people associated with it) over the marshlands (and all things associated with them). Because Hindu kings preferred to establish their kingdoms in the jāngala region to the west, it held greater geo-political value as well as economic value as the centre of Indian agriculture. The jāngala-drylands-west and ānūpa-marshlands-east polarity in ancient Indian medicine also divided health and disease, agriculture and wilderness, Aryan versus non-Aryan peoples. This dividing line was not merely symbolic but social; it was a value judgment on the social division between the alleged superiority of people from the jāngala-drylands-west compared to those from the ānuppamarshlands-east region. 
medical field and in society. Instead of the west being valued over the east, as in ancient Indian medicine, however, the north was superior to the south, northwest valued over southeast. The binary in classical Chinese medicine current during the Ming dynasty looked like this: northwest-north-dry-cold-highlands-frugality-robust bodies and southeast-south-damp-hot-lowlands-indulgence-weak bodies. Ming physicians admired the simple life of northerners over the life of leisure of southerners and favoured restraint over pleasure, though none suggested either that they or their patients should move north.

\section{Origins and representations of the northwest-southeast polarity}

\section{(1) Mythological origins: Gong Gong butts into Mount Buzhou}

The earliest textual origins of the uniquely Chinese northwest-southeast polarity relates to a story about the destroyer god Gong Gong recorded in the 'Heavenly Questions' (Tian wen 天問) chapter of the Plaints of Chu or Songs of the South (Chu ci 楚辭). ${ }^{13}$ Although this book contains a small number of works by followers and imitators, most of the poetical works in this collection are attributed to Qu Yuan 屈原 (c. 343-c. 277), a nobleman who was a contemporary of King Huai 王懷 (reigned during last quarter of the fourth century BCE)..$^{14}$ The passage from the 'Heavenly Questions' succinctly reads: '[When] Kang Hui [= Gong Gong] was enraged; why did the land lean southeast?' (Kang Hui feng nu, di he gu yi dongnan qing 康回馮怒, 地何故以東南傾? $)^{15}$

The Book of Master Lie (Liezi 列子, c. $300 \mathrm{CE}$ ) preserved one of the earliest responses to this question. ${ }^{16}$ The Liezi version attributed the northwest-southeast imbalance of yin-yang in the world to a fight between Gong Gong and the second of the first five rulers Zhuan Xu.

It follows that heaven and earth are 'things' like the things within them; and things have imperfections. That is why in ancient times Nuwa

13 I follow the argument in Allan 1991, p. 68.

14 Hawkes 1993, pp. 48-55.

15 See translations by Hawkes 1985, p. 128, lines 33-5; Field 1986, \#35; and Major 1993, p. 64.

${ }_{16}$ Although the Liezi is attributed to an early Taoist Lie Yukou 列繁寇 (c. 400 $\mathrm{BCE}$ ), it was not written down until around $300 \mathrm{CE}$, probably by one anonymous author. See Graham 1990, p. 12; and Barrett 1993, pp. 298-308. 
smelted stones of all the five colours to patch up the flaws, and cut off the feet of the turtle to support the four corners. Afterwards, when Gong Gong was fighting Zhuan Xu for the Empire, he knocked against Mount Buzhou in his rage, breaking one of the pillars of heaven, snapping one of the threads, which support the earth. For this reason heaven leans North West, and the sun, moon and stars move in that direction; the earth does not fill the South East, so the rivers and the rain floods find their home there. ${ }^{17}$

A similar early version of this story is preserved in the Huainanzi (c. second century BCE), for which the king of Huainan, Liu An 劉安(179?-122 BCE), served as general editor. ${ }^{18}$ John Major succinctly explained the astronomical significance of this account by concluding that 'the last part of this section ${ }^{19}$ recounts the famous story of the fight between Gong Gong and Zhuan Xu that led to the tilting of heaven and earth - in cosmological terms, to the astronomical fact that the ecliptic (the sun's apparent path around the earth as seen against the fixed stars) does not coincide with the celestial equator (the earth's equator as projected onto the fixed stars)' ${ }^{20}$

Although the Book of Master Guan (Guanzi 管子, fifth-first century BCE, compiled c. 26 BCE by Liu Xiang 劉向) and Discourses of the States (Guoyu 國語, contents date from 431-314 BCE) contained other stories about Gong Gong, only the accounts in the Liezi and the Huainanzi recounted his destruction of Mount Buzhou and the subsequent toppling of one of the eight earthly pillars believed to hold up the canopy of the sky. ${ }^{21}$ [See Figure 1].

The eight pillars featured in this cosmological myth were designed to explain two problems: 1) why the Celestial Pole around which the sky appears to revolve was not directly overhead in the sky, which should be the case in an ideal universe, but rather was north of it; and 2) why the earth (namely China proper) inclined downwards towards the southeast, causing the major rivers to flow in an

17 Gujin luli kao, juan 9. I use a Ming source for this story to emphasise that it was a story in circulation at that time. I adapted the English translation of this passage in Graham 1990, p. 96, by using pinyin.

18 Major 1993, p. 3-5. See Huainanzi, 3/la-b. Translations in Major 1993, p. 62, lines 23-9; Hawkes 1985, p. 136; Allan 1991, p. 68; Birrell 1993, 69.

19 Namely, the first section titled 'The origin of the cosmos' in Huainanzi, ch. 3, 'The treatise on the patterns of heaven' (tianwenxun 天文訓).

${ }^{20}$ Major 1993, p. 64.

${ }^{21}$ See the section on 'Kung Kung Butts into the Mountain' of chapter four 'Destroyers' in Birrell 1993, pp. 97-8. 


\begin{tabular}{|c|c|c|}
\hline $\begin{array}{c}\text { Northwest Pillar }= \\
\text { Mount Buzhou }\end{array}$ & North Pillar & Northeast Pillar \\
\hline West Pillar & & East Pillar \\
\hline Southwest Pillar & South Pillar & Southeast Pillar \\
\hline
\end{tabular}

Fig. 1. The eight earthly pillars that hold up heaven

easterly direction. The myth explained why the cosmos is askew rather than perfect and symmetrical, as one would expect based on a balance of yin and yang. ${ }^{22}$ One oft-repeated phrase in a wide range of sources from commentary on the Book of Changes (Yijing 易經) to calendars thereafter summarised the geographic consequences of this ancient cosmic battle in Chinese mythology: 'Heaven tilts in the northwest' (Tian qing xibei 天傾西北), or sometimes 'Heaven is insufficient in the northwest' (Tian buzu xibei 天不足西北), and 'Earth is incomplete in the southeast' (Di buman dongnan 地不滿東南). Illustrations of this geographic concept do not appear to circulate, however, until the late-Yuan and Ming dynasties.

\section{(2) Visual Representations of the northwest-southeast polarity}

At least three types of images of this geographic concept 'Heaven is insufficient in the northwest; earth is incomplete in the southeast' circulated during the Ming: geographic relating to the imagined form of heaven and earth, numerological relating to the hexagrams of the Book of Changes, and medical related to the macrocosm-microcosm model. These images illustrate the multiple levels of meaning this ancient concept carried not only within the medical sphere, but also in Chinese culture generally. ${ }^{23}$ In the interest of space, I focus on the geographic image printed in the earliest extant Yuan edition

${ }_{22}$ Summary of argument and chart in Hawkes 1985, pp. 135-6.

${ }^{23}$ The second image is of the 64 hexagrams of the Book of Changes (Yijing 易經) arranged according to the four cardinal directions. It comes from the The Imperial Longevity Permanent Calendar (Shengshou wannian li 聖尋萬年歷), which the Ming prince Zhu Zaiyu 朱載埍 (1536-1611) published in 1595. The third image is of the palmside of the left hand, which the late-Ming physician Zhang Jiebin 張介耍(1563-1640) published in the Leijing tuyi 類經圖翼 (Illustrated Commentary of the Classified Canon, 1624). See the longer Chinese version of this article for a discussion of all these images. 
(r. 1330-1333) of the encyclopaedia titled the Broad-ranging Record on Many Matters (Shilin guangï 事林廣記), which the Southern-Song scholar Chen Yuanjing 陳元靚 (c. 13th century) compiled. The image titled the 'Diagram of the two appearances and two luminaries' (Liangyi liangyao zhi tu 兩儀兩曜之圖) appeared on the first page of the Yuandynasty edition directly following Zhou Dunyi's 周敦頣 (10171073) famous diagram of cosmological process titled the 'Diagram of the great unity' (Taiji $t u$ 太極圖). ${ }^{24}$ [See Figure 2]. The top of the image is north and the bottom is south. The three-legged black bird of mythology resides in the sun on the upper right side, corresponding to the northeast. The elixir-producing rabbit of mythology lives on the moon in the upper left side, corresponding to the northwest. Mountains associated with earth fill the upper left side where 'Heaven tilts in the northwest' (Tian qing xibei 天傾西北). Ocean waters fill the lower right side where 'Earth is incomplete in the southeast' $(\mathrm{Di}$ buman dongnan 地不滿東南). The result is a skewed 'plate tectonics' in which earth slants up toward the northwest taking space where heaven should be, and then slides down toward the southeast where water takes the place where earth should be.

Two essays accompanied this image explaining the cosmological processes represented therein. The 'Explanation of the diagram of the two appearances' (liangyi tu shuo 兩儀圖説) discussed the interdependent yin-yang relationship between heaven and earth by quoting from several classical texts, including the statement from the Inner Canon of the Yellow Emperor: Basic Questions (Huangdi neijing: suwen 黄帝内經: 素問, c. first century BCE) that 'Heaven is insufficient in the northwest therefore the northwest region is yin' (Tian buzu xibei, gu xibeifang yin ye 天不足西北, 故西北方陰也). ${ }^{25}$

The "Explanation of the diagram of the two luminaries' (liangyao tu shuo 兩曜圖 説), on the other hand, elaborated on the yin-yang relationship between the sun and the moon, describing the legends that go back to late-Zhou mythology of the three-legged bird in the sun and the rabbit in the moon (formerly the goddess Chang $\mathrm{E}$ 常娥 who

\footnotetext{
${ }^{24}$ [Zuantu zengxin qunshu lei yao] Shilin guangï, Yuan Zhishun reign edition, juan 1, p. 2.

${ }^{25}$ For history and dating of the Inner Canon of the Yellow Emperor: Basic Questions, see Sivin 1993. Quotation in 'Major essay on the resonance and appearance of yin and yang' (Yin yang yingxiang dalun 陰陽應象大論), Ren 1986, 5 pian, 4 zhang, 3 jue, p. 22. (See ninth line in passage in figure 2.)
} 

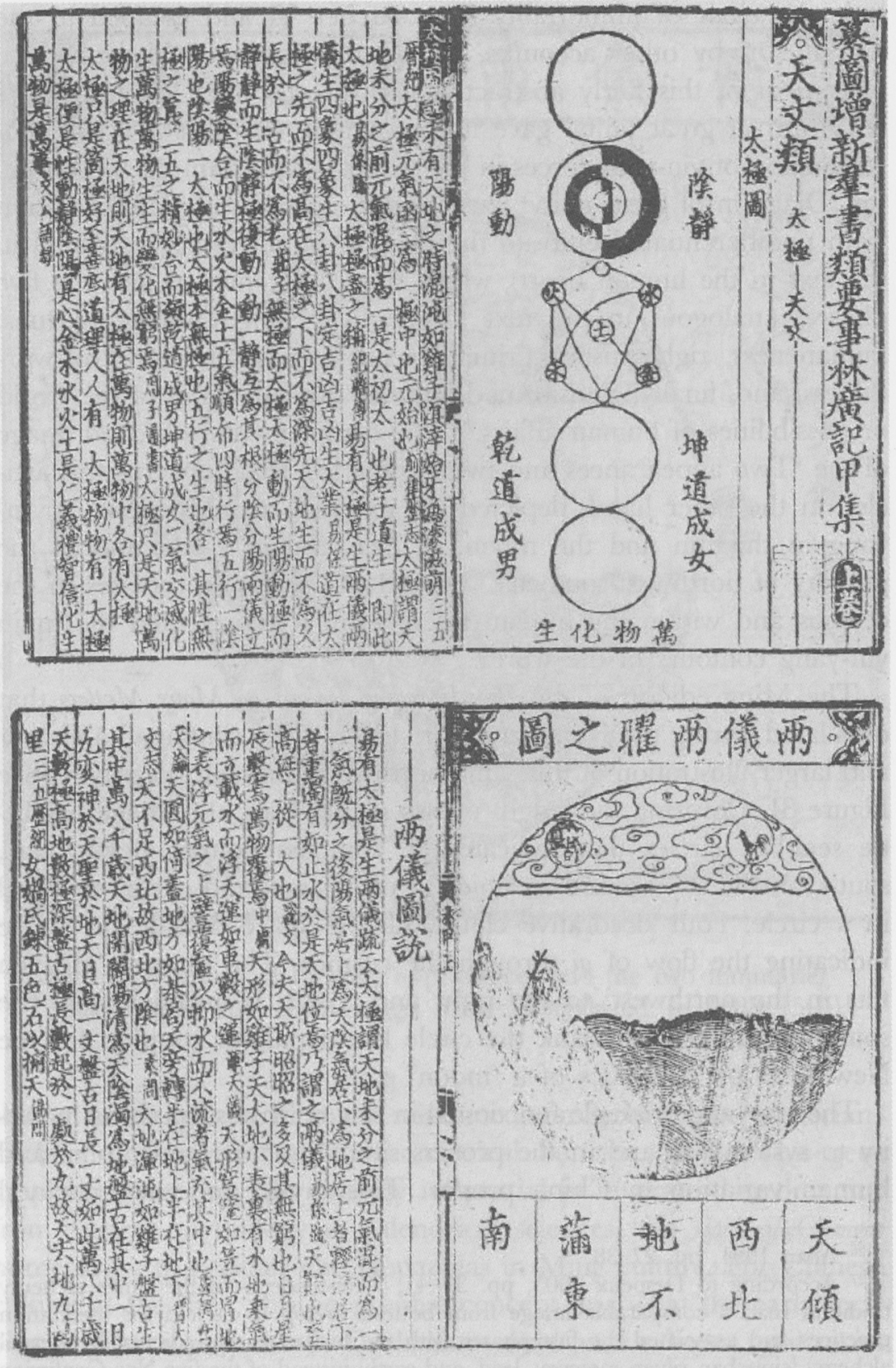

Fig. 2. 'Diagram of the two appearances and the two luminaries' [Zuantu zengxin qunshu lei yao] Shilin guangï, Yuan Zhishun ed. (r. 1330-1333) 
stole the elixir of immortality from Archer $\mathrm{Yi}$ and escaped to the moon). Or, by other accounts, a toad resides on the moon. ${ }^{26}$ The placement of this fairly abstract image directly after Zhou Dunyi's 'Diagram of great unity' gave it comparable status as a visual representation of yin-yang forces in the world. Read from top to bottom, the 'Diagram of great unity' illustrated the process of transformation from undifferentiated unity to the division of yin-yang (correlated in the text to the human heart), which then differentiated into the five phases (analogous in the text to the five Neo-Confucian virtues: humaneness, righteousness, ritual decorum, wisdom, and trustworthiness) and, finally, transformed into the myriad things of the world or possibilities of human affairs. ${ }^{27}$ The complementary second image of the 'Two appearances and two luminaries' that concerns this article, on the other hand, depicted the external manifestations of yinyang in the sun and the moon, in heaven and earth, and in the polarity of northwest-southeast. Instead of universal processes in the cosmos and within the human microcosm, it represented the main yin-yang contours of the world.

The Ming edition of the Broad-ranging Record on Many Matters that circulated during the Hongwu era (r. 1488-1505) contained a clearer and larger illustration of this same northwest-southeast polarity. ${ }^{28}$ [See Figure 3]. Covering the length of two facing leafs, the image has little seal-like circles that indicate the compass points - north, east, south, and west - around a depiction of 'heaven and earth' enclosed in a circle. Four decorative clouds fill the space outside the circle indicating the flow of $q i$ through the cosmos. The phrases 'Heaven tilts in the northwest' to the right and 'Earth is insufficient in the southeast" to the left flank the circle like a pair of couplets for the New Year on two sides of a 'moon' gate.

The yin-yang principle functioned in this northwest-southeast polarity to systematise and in the process simplify actual geographic and human variation in China proper. This myth, and the imagined

\footnotetext{
${ }^{26}$ Allan 1991, pp. 27-38.

27 According to Despeux 2005, pp. 39-41, Taoist adepts of the inner alchemy tradition read a comparable image from bottom to top as an aid for meditation practices and associated the five phases with the five main ingredients of internal alchemy (cinnabar, silver, mercury, lead, and earth) instead of the five Neo-Confucian virtues as in this example.

${ }^{28}$ [Zuantu zengxin leiju] Shilin guangï, Ming Hongzhi reign edition, juan 1, pp. 2b-3a. Taipei facsimile.
} 


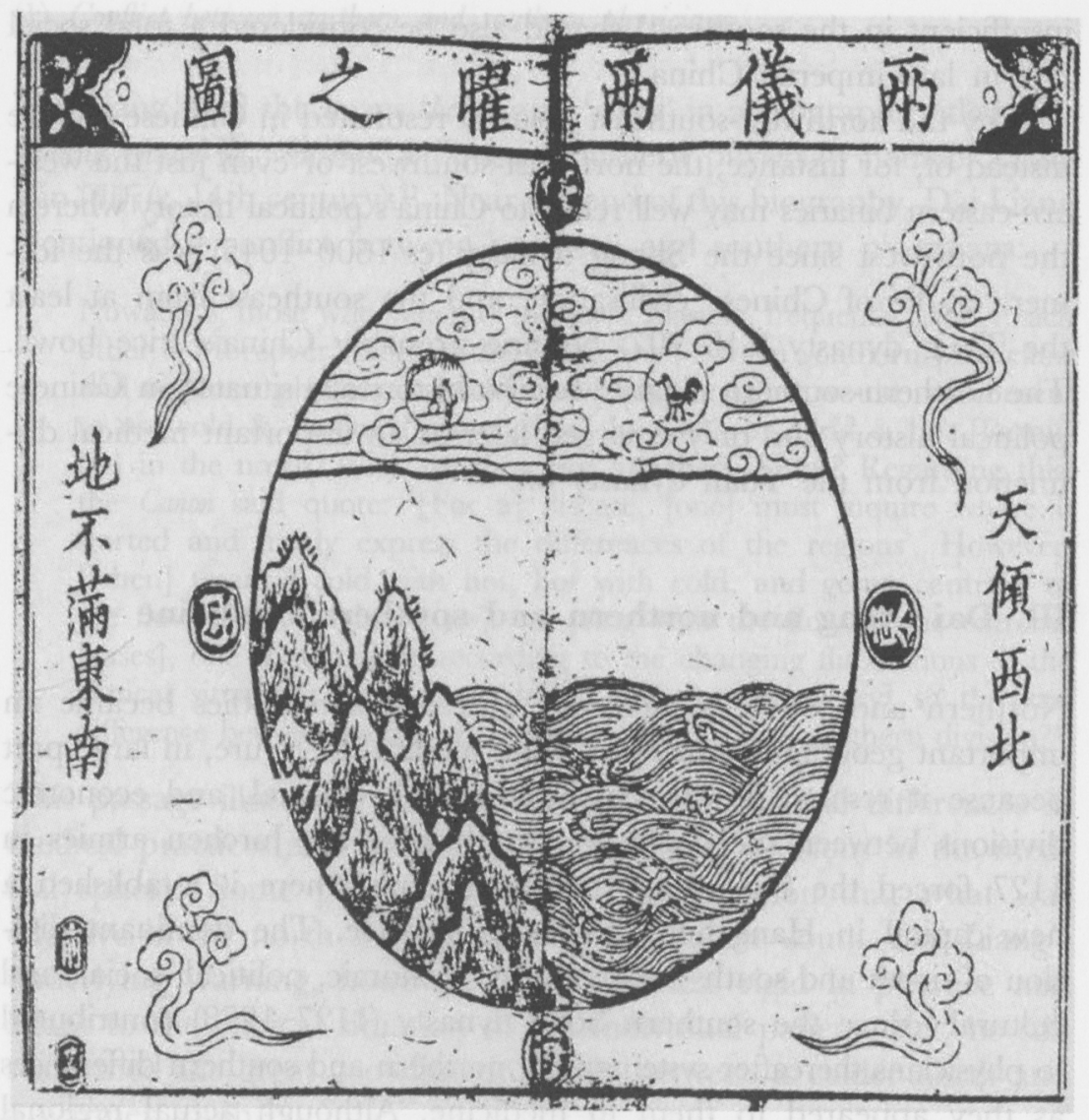

Fig. 3. 'Diagram of the two appearances and the two luminaries' [Zuantu zengxin leiju] Shilin guangii, Ming Hongzhi ed. (r. 1488-1505).

skewed geography of China it reinforced, similarly helped physicians explain an imperfect and asymmetrical human society. This geographic conception was broadly influential in several other domains from ancient mythology to calendrical sciences, the Book of Changes numerology to popular encyclopaedias in Ming culture. For Chinese culture at the time, this geographic concept was what the early sociologist of knowledge Emile Durkheim would have called a total social fact. Just as Zimmerman defined the specific Hindu reality of the jāngala or jungle as a total social fact in the Durkheimian sense, the specific Chinese reality of 'Heaven tilts in the northwest; earth is 
insufficient in the southeast' should also be considered a total social fact in late imperial China. ${ }^{29}$

Why the northwest-southeast polarity resonated in Chinese culture instead of, for instance, the northeast-southwest or even just the western-eastern binaries may well relate to China's political history wherein the northwest since the Shang dynasty (c. 1600-1045) was the former 'cradle of Chinese civilisation' and the southeast from at least the Tang dynasty (618-907) became arguably China's 'rice bowl'. The northern-southern binary was also historically situated in Chinese political history and only emerged later as an important medical distinction from the Yuan dynasty on.

\section{Dai Liang and northern and southern medicine}

Northern and southern medicine, climates, and bodies became an important geographic binary in Ming medical literature, in large part because it resonated with perceived social, cultural, and economic divisions between the north and south after the Jurchen armies in 1127 forced the Song court to move south where it established a new capital in Hangzhou, Zhejiang province. The dominant division of north and south - agricultural, economic, political, social, and cultural - since the southern Song dynasty (1127-1278) contributed to physicians thereafter systematising northern and southern differences as they appeared to them in medicine. Although actual regional differences in medical practices existed throughout Chinese history since antiquity, the earliest mention of differences between specifically 'northern medicine' or 'northern physicians' (beiyi 北醫) and 'southern medicine' or 'southern physicians' (nanyi 南醫), did not enter the historical record until the end of the Yuan dynasty. Two biographies of physicians in the collected writings, Fiuling shanfang $\ddot{j}$ 九靈山房集 (Compilation of the Mountain Villa of Nine Divinities), of the late-Yuan and early-Ming literatus Dai Liang 戴良 (1317-1383) offer the richest evidence of a broader conception of northern and southern differences in medical practice. ${ }^{30}$

${ }^{29}$ Zimmerman 1987, p. 219.

${ }^{30}$ For this source and argument, see Leung 2002, p. 170. 


\section{(1) Conflict between northern and southern physicians}

Dai Liang used the terms 'beiyi' and 'nanyi' in a biography titled 'Bao Yiweng zhuan'抱一翁傳 of a famous southern physician named Xiang Xin 項昕 (c. 14th century). ${ }^{31}$ Near the end of this biography, Dai Liang mentioned a conflict between northern and southern physicians:

Nowadays, those who venerate the three masters, frequently slander each other ${ }^{32}$ Moreover, there is the difference between southern physicians and northern physicians [such] that [they] certainly would not consent to use cold \& cooling [formulas] in the south or acrid \& hot [formulas] in the north. Why are they [so] attached to this? Regarding this, the Canon said quote: '[For a] disease, [one] must inquire where it started and firmly express the differences of the regions'. However, [when] treating cold with hot, hot with cold, and going contrary to the flow of the slight [cases], or going with the flow of the extreme [cases], one should treat according to the changing fluctuations of the clinical situation. How could [one] limit [one's inquiry] to the vast difference between cold and hot due to the norhern-southern division? ${ }^{33}$

This passage illustrates how the discourse on regional differences in medical practices also reveals significant social divisions in the medical sphere. Some physicians were of the opinion that what was effective in the north should not be taken in the south. Dai Liang's underlying warning, however, was to be less rigid in practice and adapt to the clinical situation of the individual patient. Yet, he still reaffirmed the great geo-climatic divide between a colder north and a warmer south. ${ }^{34}$

\section{(2) Northern purgatives versus southern restoratives}

In another essay, Dai Liang recounted a conversation he had with the Suzhou doctor Zhu Bishan 朱碧山 (c. 14th century). ${ }^{35} \mathrm{He}$ asked Doctor Zhu why physicians in the southeast do not use the same approach as do northern doctors who used purgatives to expel the

${ }^{31}$ Li Yun, 1988, pp. 644-45; He Shixi 1991, pp. 773-74.

32 These three doctors were Liu Wansu, Zhang Congzheng, and Li Gao.

33 Jiuling shanfang $j i$, juan 19. For use of this source, see Leung 2002, p. 170.

${ }^{34}$ It is noteworthy that based on the origins of the southern physicians Dai Liang wrote about, the 'south' refers to the Jiangnan region in Central China, and not the 'far south', which would have included Guangdong and Guangxi provinces.

${ }^{35}$ Li Yun, 1988, p. 177; He Shixi 1991, p. 246. 
illness-causing agent. In response, Zhu Bishan described northern and southern differences not only in terms of appropriate therapies, but also with respect to climate, body types, eating habits, and pleasures.

One day I was talking with the Wu physician Zhu Bishan about this and Bishan changed expression and said: 'You sir are truly a northern scholar; you understand northern medicine and that is all. Medicine originally did not have a difference between north and south, but those who are familiar with its teachings are suitably informed about it. The northern wind and $q i$ are turbid and thick, constitutions are powerful and robust, and combined with their simple and generous and frugal and simple diet and desires, no one suffers from violence or loss of vitality through dissipation. As soon as [someone] falls sick, [they] then use a bitter cold clearing beneficial formula to throw [it out], and thereby quickly [bring the patient back] to good health and spirits.

As for southern people, [their] constitutions are soft and fragile, the pores of their flesh are loose and shallow, [they] indulge in food and drink, have excessive desires, [all of] which is completely different from northerners. But if you wish to use the previous method [i.e., the bitter cold clearing formula] to treat them, it would be no different from using a knife to murder someone. Thus to treat illnesses in the north it is best to take as the first [option] using attack [formulas] to strike down the external pathogenic (xie 邪) [qi]; to treat illnesses in the south, it is best to take as the root [therapy], using protecting [formulas] to nourish the inner $q i$. That is the meaning of this. ${ }^{36}$

This passage represents what became a typical conception of northern and southern medical differences. ${ }^{37}$ At that time, it also expressed an underlying anxiety about the ill affects of a decadent southern lifestyle of over-indulgence in foods and pleasures. ${ }^{38}$ Dai Liang used regionalism here to criticise an intemperate southern culture in favour of the simpler more frugal northern culture from which he came and of which he implicitly embodied.

\section{(3) The northern patient takes southern restoratives}

Dai Liang contrasted the stronger northern patient, with whom he personally identified, with the stereotype of a more delicate southern

\footnotetext{
${ }^{36}$ Jiuling shanfang $\ddot{j}$, juan 13.

37 Leung 2002, p. 170, quoted this passage as representative of the medical conceptions of northern and southern differences from then on after the Yuan dynasty.

${ }^{38}$ For a comparable analysis of anxiety about the immoderate appetites for food and sex among male patients in sixteenth-century Huizhou, see Grant 2003.
} 
patient. After spending some time in the south as an official and becoming sick, however, he also found that the northern purgative therapies of his home were not always the most appropriate interventions while living in Jiangnan.

When I was an official in Jiangsu and Zhejiang, Bishan was the imperial physician for the province. During my wanderings, I became sick so that it was necessary to seek out Bishan. However, each time Bishan used 'protecting and nourishing formulas' (baoyang zhi $j i$ 保養之劑) in order to get it. It was effective because, although I am a northern product, I had lived in the south for a long time and so it was also no longer appropriate to devote myself exclusively to purgatives (gongfa 攻伐) and probably [should now be] cautious about them.

My mother is very elderly so when she encounters an illness, it is quite serious. All of the Wu physicians said that only Bishan's medicinal strategy [i.e., protecting and nourishing formulas] would be suitable. And I had a case of 'collapsed Blood' (wangxue bing 亡血病), for which I had taken drugs for many years. Bishan examined me and said: 'This is a yin depletion syndrome. Slowly take restoratives for it, and [you will be] cured.' Impatient, [I] stopped and then had a major set back. From then on [I] used his method [i.e., restorative formulas] and in less than two months was cured. ${ }^{39}$

This appears to be the first case where a northerner explicitly expressed that living in the south had changed his strong constitution so much so that he had contracted an illness of 'yin depletion' (yinxu 陰虛). Dai's underlying message about northern-southern medical regionalism in his preface for the southern doctor Zhu Bishan remains the same as in his biography of Xiang Xin. While physicians (and northern patients like himself) should be aware of northern and southern differences in climates and constitutions, they should not adhere rigidly to either northern or southern therapeutic styles. He found that living in the south could change a northerner's robust constitution into a southern case of yin depletion. Although Dai clearly preferred the eliminating rationale of 'northern purgatives' through this account of his own healing experience, he also valorised the replenishing rationale of 'southern restoratives' as a regionally appropriate therapy.

If Dai Liang's observations of northern purgatives and southern restoratives could be read as also expressing the broader body relations

39 Jiuling shanfang ji, juan 13. 
of power in society during the Yuan dynasty, then the medical attention to eliminating external pathogens appears particularly well suited for a body politic concerned about external invasion along its northern borders; conversely, the emphasis on restoring internal depletion appears socially resonate for a subservient southern body politic anxious about depleting its resources and strengthening its internal core..$^{40}$ A comparable body-society semiotics ${ }^{41}$ can be found in the writings of a Qing physician reflecting back on the fall of the Song and the Chinese loss of the north to Jurchen control in 1127. The mid-Qing physician scholar Xu Dachun 徐大椿 (1693-1771) delineated the relationship between the somatic and political body in an essay titled 'Illnesses follow the fate of states' (Bing sui guo yun lun 病隨國運論) published in a 1757 collection of his essays. He directly related the fall of the Song dynasty, subsequent loss of China's central plain, weakening of the head of state and slackening of his ministers (zhu rou chen chi 主弱臣弛) to the therapeutic innovations of the Chinese physicians Zhang Yuansu 張元素(c. 12th century) and Li Gao 李杲 (1180-1251). Both physicians lived in the north under the Jurchen established Jin dynasty. In response to the weakened Chinese body politic, $\mathrm{Xu}$ argued, these physicians emphasised formulas that restored the 'central palace' (bu zhonggong 補中宮), 'strengthened the spleen and stomach' (jian pizvei 建脾胃), ${ }^{42}$ and contained drugs with hardy and dry qualities to bolster yang $q i^{43}$

Whether or not contemporary Yuan physicians were conscious of this kind of body-society semiotics, Dai Liang's writings nevertheless brought to the fore a new tension between northern and southern physicians and their respective therapeutic preferences characteristic of the age. This tension, however, does not appear to have been explicitly discussed in a medical text until over 100 years later; but this time in the writings of a southern scholar-official that date to the first decade of the sixteenth century.

${ }^{40}$ For articles on how the human body, organs, and bodily substances have also been used as models for the ideal functioning of human society and to naturalise political institutions in other cultural and historical contexts, see Feher et al. (eds) 1989.

${ }^{41}$ For theory of body-society semiotics, see Douglas 1982; and reassessment in Schatzki, T. R. and W. Natter 1996.

42 The spleen being associated with the earth phase and the central region of China in the five phases system of correlations symbolically corresponded also to Chinese ethnic and political identity here.

${ }^{43}$ Unschuld 1990, pp. 239-41. 


\section{Wang Lun and Enlightened Physicians}

The wide range of essays in one of the earliest Ming medical primers, the Miscellaneous Writings by Enlightened Physicians (Mingyi zazhu 明醫雜著, 1502), offers a useful entry point into the Ming debates on medical regionalism. The author, Wang Lun 王綸 (fl. 1484-1521), was from Cixi 慈溪 county in Zhejiang province. Wang was foremost a scholarofficial who in 1484 received the jinshi degree, which granted him a place in the Chinese imperial bureaucracy as a secretary in the Ministry of Works. He rose in government positions until he served as the Right Vice-Censor-in-Chief and Grand Coordinator of Huguang from 1506 to $1521 .{ }^{44}$ As an official of the central imperial government, he was sent to coordinate and supervise provincial-level agencies in these provinces. In such a high position, he was a member of the highest elite, but instead of writing poetry, prose, or historyas many men of his status did - he became most famous for one of his published writings on medicine. ${ }^{45}$

\section{(1) Wang Lun's medical regionalism}

Of over 75 essays in Enlightened Physicians, two provide direct evidence on how Wang Lun thought about northern and southern differences and where he learned his views on medical regionalism: 1) 'On different methods being regionally suited' (Yifa fangyi lun 異法方宜論) and 2) 'If one asked about the treatment methods of Dongyuan [ $\mathrm{Li}$ Gao 李朵 (1180-1251)] and Danxi [Zhu Zhenheng 朱震亨 (12821358)]' (Huowen Dongyuan Danxi zhibing zhi fa 或問東 垣丹溪治病之法). ${ }^{46}$ Wang Lun used a range of geographic and climatic vocabulary to express his take on medical diversity and human variation within China.

In the first essay, Wang relied on the northwest-southeast axis, which was depicted in the Yuan encyclopaedia Broad-ranging Record

${ }^{44}$ Huguang encompasses the two provinces, Hubei and Hunan.

${ }^{45}$ He Shixi 1991, pp. 44-5; Li Yun 1988, p. 49. Although three other books are attributed to him, the one that made him known and is still being reprinted is the Mingyi zazhu [Miscellaneous Writings by Enlightened Physicians].

${ }^{46}$ Mingyi zazhu, juan 1, p. 3; juan 3, pp. 106-7. A third essay titled 'Intention to treat Lingnan's various disorders' (Ni zhi Lingnan zhubing 擬治嶺南諸病), juan 2, pp. 82-6, could have also been included under 'Ming medical regionalism' but since other scholars have already analysed the history of medical views of the Lingnan region and diseases of the far south since the Tang dynasty, in the interest of space I chose not to include this essay in my analysis. See Xiao Fan 1993 and Leung 2002. 
on Many Matters. Here he employed the terms 'southeast' and 'northwest' to refer to regional characteristics: different qualities of climatic $q i$, levels of land, relative dryness or dampness, regional use of pepper and ginger, and whether cold or hot types of drugs are recommended. In the second essay, he developed further Dai Liang's northern-southern dichotomy in medicine by differentiating not only the particular climatic $q i$ of the 'southern region' (nanfang 南方) and the 'northern region' (beifang 北方), but also by discussing separately 'southern illnesses' (nanbing 南病) and a 'southern physician' (nanyi 南醫) from 'northern illnesses' (beibing 北病) and a 'northern physician' (beiyi 北醫). He also specified four other regions: Shaanxi 陝西 in the northwest, Jiang Zhe 江浙 (Jiangsu and Zhejiang provinces), Jiang $\mathrm{Hu}$ 江湖 (Jiangxi and Hunan) ${ }^{47}$ of central China along the middle reaches of the Yangzi river, and Lingnan 嶺南 (Guangdong and Guangxi provinces) in the far south. Wang Lun's essays offer a representative range of the regional terminology that informed the practice of literate Ming physicians at the very beginning of the sixteenth century.

\section{On eating acrid and hot foods}

The problem of regional variation in medical practice appears in the third essay of Enlightened Physicians 'On different methods being regionally appropriate' (Yifa fangyi lun 異法方宜論). Wang Lun discussed regionally different eating habits of acrid and hot spices that appeared to be contrary to accepted uses of these substances as drugs in the classical medical tradition.

Someone asked: People say that the $q i$ of the southeast is hot, [so it is] appropriate to prescribe cold medicines; the $q i$ of the northwest is cold, [so it is] appropriate to prescribe warm medicines. However, why is it that these days southeastern people often consume black pepper, ginger, and cassia bark, [yet we] do not see them get sick; yet, northwestern people avoid consuming acrid and hot substances such as black pepper and ginger?

${ }^{47}$ This phrase is often translated literally as the 'rivers and lakes' or 'to travel' and metaphorically refers to 'itinerant entertainers and charlatans' or those who ply their trade on the waterways and byways. In the context of Wang Lun's essay, however, the two terms more likely refer to the first characters of the names of two provinces next to each other, as are Jiangxi and Hunan. 
On the surface, his answer to this conundrum was simple:

This is because although it is hot in the southeast, the land is low lying and damper; acrid and hot foods and drugs [such as black pepper, ginger, and cassia bark] can also expel the dampness. Although it is cold in the northwest, the land is mountainous and dryer; acrid and hot foods and drugs can conversely exacerbate the dryness. Those who use drugs to treat illnesses must understand the meaning of this. ${ }^{48}$

Wang Lun focused on the regionally different culinary practices of consuming acrid hot spices in a hot climate and avoiding the same in a cold climate precisely because these practices challenged the maxim in classical Chinese medicine 'to treat hot with cold and cold with hot' (rezhe han zhi; hanzhe re zhi 熱者寒之, 寒者熱之). He solved the apparent contradiction, by arguing that the relative dryness of the climate in the northwest and dampness of the climate in the southeast complicated the cold-hot distinction. Because acrid substances disperse and move $q i$, the black pepper, ginger, and cassia bark in south-eastern cooking assists in drying out the dampness people living there contracted from their climate. The same spices may be good for countering the cold of the north-western climate, but their acrid quality also exacerbated the dryness of those who lived there by further dispersing their $q i$.

Wang Lun solved the contradiction by employing geo-climatic distinctions of a dryer (as well as colder) northwest and a damper (as well as hotter) southeast. He strategically used this regional variation in preferences for and taboos against acrid hot substances to complicate the simplistic notion with which he opened the essay. Writing a medical primer, he assumed that some of his potential readers might believe that physicians prescribed hot drugs to those living in the northwest to counter the effects of a cold climate and cold drugs to those in the southeast to counter the effects of a hot climate. Here he attempted to teach the novice reader to reason with greater subtlety and consider multiple climatic factors beyond just hot and cold.

On Xue Fi's regional constitutions and Su Shi's 蘇軾 formula Shengsanzi 聖散子

Although Wang Lun did not impart a value judgment on the binary expressed in this essay-namely, the northwest-cold-dry taboo on

${ }^{48}$ Mingyi zazhu, juan 1, p. 3. 
acrid hot spices and the southeast-hot-damp preference for acrid hot spices - his later commentator clearly did. Thirty years after Wang Lun's death, Xue Ji 薛己 (1487-1559) wrote a preface to, commented on, and had republished Enlightened Physicians in $1551 .{ }^{49}$ Xue Ji's commentated edition is the only version of Enlightened Physicians that remains today. Its preservation is due in large part to having been included in two collections of Xue Ji's commentary and editorial work on the medical texts of other physicians. ${ }^{50}$ Xue Ji was born into a family of hereditary physicians in Wu prefecture of Jiangsu province, now modern-day Suzhou city. His father, Xue Kai 薛鎧 (c. late15 th century), was a physician in the imperial medical bureau during the Hongzhi reign (r. 1488-1505) and a contemporary of Wang Lun who was a secretary in the Ministry of Works during the same reign. Xue Kai was promoted to Commissioner of the medical bureau and was known for his work in paediatrics. ${ }^{51}$ Upon the death of Xue Kai in 1508, Xue Ji took his father's place as a physician in the Imperial Medical Bureau, where it is possible that he had contact either with Wang Lun himself (concurrently the Right Vice-Censorin-Chief and Grand Coordinator of Huguang from 1506 to1521) or, at least, the original editions of his books. He worked there until 1512 when an injury from a vehicle accident compelled him to return to his native Suzhou to recover. In 1519, however, he moved up to the sixth rank in the imperial medical bureau of Nanjing. In 1530, he left the imperial medical service as a fifth ranked physician in order to devote his energy to medical practice and publishing. ${ }^{52}$

The official Shi Qianwei 石錢薇 (c. 1549-51) endorsed Xue Ji's edition of Enlightened Physicians by writing a preface to it and thus lending his prestige as an official to ensure its success. Furthermore, he expressed an awareness of medical currents (yipai 醫派) of regional

${ }^{49}$ He Shixi 1991, pp. 277-80; Li Yun 1988, p. 952.

50 The 1985 version of the book edited by Wang Xinhua was based on the 1551 Song Yangshan blockprint, the earliest known edition of the Mingyi zazhu. The Mingyi zazhu may well have been preserved and was more widely distributed than Wang Lun's other medical texts because the more prolific and influential Ming physician Xue Ji wrote a commentary to it and published it in two collections of his own and others' works he edited, arranged, or wrote commentary on: the $\mathrm{Mr}$ Xue's Medical Case Histories, 24 Kinds (Xueshi yi'an ershisi zhong) and Mr Xue's Medical Case Histories, 16 Kinds (Xueshi yi'an shiliu zhong). See also Xu Senyu (ed.) 1986, p. 820 (left).

${ }^{51}$ Xue Ji revised and self-published his father's book on paediatrics titled the Abstracts on protecting infants (Baoying cuoyao 保嬰撮要, 1556).

${ }^{52}$ Also see Cheng Weizhong (ed.) 1999, pp. 1091-3. 
learning by praising the role of Suzhou (Gusu 姑蘇) physicians in transmitting in the south the medical learning of the northern physicians Liu Wansu 劉完素 (1120?-1200) and Zhang Congzheng 張 從正 (1156?-1228). Already in 1549, when Shi Qianwei wrote this preface, he had a clear sense of a Suzhou 'current of learning' in medicine and that he considered both Wang Lun and Xue Ji to be part of it. ${ }^{53}$ In his preface to Enlightened Physicians, on the other hand, Xue Ji emphasised Wang Lun's concern for the people's welfare during epidemics and the efficacy of his fever treatments. His commentary to Wang Lun's essays expressed his own thoughts on Wang's conclusions and recommended additional courses of therapy.

Xue argued, for example, that the regional differences in the consumption (or not) of acrid hot spices, which Wang Lun used as an illustration of simplistic reasoning, were in fact due to regional differences in bodily constitutions. It was not the climatic differences in hot or cold, damp or dry that explained the regional preference for or against acrid and hot substances, but rather the relative fullness or depletion of the yang $q i$ within the people themselves of each region:

The southeastern regions are low lying, damp, and hot; the pores of the people there are loosely opened (couli shutong 㬺理疏通), so their sweat and ye fluids drain out and their yang $q i$ is depleted within. Thus, it is appropriate for them to eat black pepper, ginger, and such acrid and hot things in order to boost their yang qi. [However,] the northwestern regions are high, mountainous, windy, and cold; the pores of the people there are tightly closed (couli zhimi 㬺理緻密), so that their sweat and ye fluids are secure within, and their yang $q i$ is complete and full. It is not appropriate for them to eat black pepper, ginger, and such acrid and hot things, which would contrarily boost their yang $q i^{54}$

Xue Ji gave an historical example from the Northern Song dynasty (960-1127) to further support his position. The famous Song official Su Shi 蘇軾 (1036-1101) was serving in Huangzhou 黄州, a prefectural

${ }^{53}$ Shi Qianwei preface to Mingyi zazhu, p. 3. For the history of transmission of this current of learning, see Wu Yiyi 1993-4, pp. 36-65. Wu argues that the editor's introductory statement on medicine in the Wenyuange Siku quanshu of 1782 'was the first to affirm the existence of such lineages among medical practitioners'. Wu Yiyi $1993-4$, p. 37. But Shi Qianwei's preface places this kind of affirmation in the mid 1550s.

${ }^{54}$ Xue Ji's commentary follows the original passage in Mingyi zazhu, juan 1, p. 3. 
city located just east of Wuhan on the Yellow River in Hubei province. During an epidemic sweeping through the region in 1089, he founded and endowed a government hospital to treat the sick and take care of the dead. ${ }^{55}$ At that time Su Shi prescribed the formula Shengsanzi 聖散子 to treat patients suffering from the disease, which from then became a popular formula for treating epidemics. ${ }^{56}$ Xue Ji wrote that this prescription was highly effective in the south precisely because the acrid and warm qualities of the drugs in the Shengsanzi formula addressed the depletion of yang $q i$ and countered the resulting cold in the southeastern patients. Xue asserted, however, that when people used this same prescription to treat epidemics in the northwest, it only led to countless deaths. This was because the acrid hot qualities of the same formula only exacerbated the constitutional dryness and brought to excess the already full yang $q i$ of northern patients. ${ }^{57}$

Although Shengsanzi effectively treated fevers in the southeast, because of corporeal differences in constitution, Xue argued, in the northwest it would only cause greater suffering from the same kind of epidemic fevers. Although Xue Ji considered full yang $q i$ better than depleted yang $q i$, thus valorising the northwest over the southeast, excessive yang $q i$ nevertheless could also kill patients.

\section{On multiple rhetorical ends of Ming medical regionalism}

This textual exchange between Wang Lun and Xue Ji reveals how a single example of geo-culinary practices - in this case the northwestern avoidance of acrid hot substances and the southeastern preference for them-could be used for multiple rhetorical ends. Wang Lun used the example to give novice readers an exception to the rule that they should treat 'hot with cold and cold with hot'. He alerted them to consider as well dampness and dryness as pathogenic factors.

Xue Ji, on the other hand, further developed the same example in a way that affirmed both constitutional differences between north-

\footnotetext{
55 Needham 2000, p. 54.

${ }^{56}$ This formula is cited in The Superlative Formulas of Su Shi and Shen Kua (Su Shen liangfang), juan 2 and 3. Neither juan of the Su Shen liangfang, however, refer to the 1089 epidemic in Huangzhou. It is discussed, however, in the Formulas for General Benefit (Puji fang 普済方), juan 151.

${ }^{57}$ Mingyi zazhu, juan 1, p. 3.
} 
western and southeastern people and regionally appropriate therapeutic interventions. Neither one of these two points was implicit in Wang Lun's original example. Xue Ji's use of medical regionalism here, by contrast, expressed an anxiety that even the most effective formula for treating fevers, Su Shi's famous Shengsanzi, was not universally effective throughout the empire. The literate medical discourse on regional variations reveals what physicians perceived at the time were limitations, biases, and shortcomings in medical practice as well as the transmission of medical knowledge.

\section{(2) Medical regionalism in the Yellow Emperor of the Inner Canon}

From what sources did Wang Lun and Xue Ji acquire these concepts of medical regionalism? The title of Wang's essay 'On different meth-

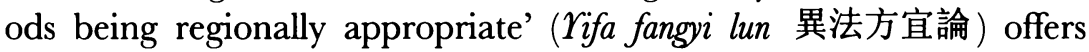
the most obvious starting point. The essay's title suggests that the 'locus classicus' of this medical regionalism is the section of the same title in the Inner Canon of the Yellow Emperor: Basic Questions. ${ }^{58}$ The curious matter, however, is that a comparison of the original Inner Canon essay with Wang Lun's essay of the same title reveals a significant divergence.

The following table presents the Inner Canon's entire chapter 'On different methods being regionally appropriate' according to the five regions (wufang 五方) that divide the essay into five jie 節. [See Figure 4a]. The top row translates the introduction to the essay and the bottom row translates its conclusion. The five columns, one for each of the five regions, are divided according to the six major differences emphasised in the essay: 1. land, 2. customs, 3. constitutions, 4. illnesses, 5 . treatments, 6 . origins of treatments. The order of the five columns from left to right-East, West, North, South, Central-follows the order of the original text. Figure $4 \mathrm{a}$ presents a complete translation of this chapter.

The chapter with the same title in the Inner Canon, however, shares neither geographic concepts nor therapeutic recommendations with Wang Lun's essay on acrid and hot foods. ${ }^{59}$ Instead of a northwestsoutheast axis, the Inner Canon version differentiated five regions. Rather than preferences for or avoidance of acrid hot substances,

${ }^{58}$ For dating, see Sivin 1993, pp. 196-215.

${ }^{59}$ Ren 1986, di 12, pp. 39-40. 


\begin{tabular}{|c|c|c|c|c|c|}
\hline 引言 & $\begin{array}{l}\text { 黃帝問曰: } \\
\text { 歧伯對曰: }\end{array}$ & $\begin{array}{l}\text { 治病也, - } \\
\text { 使然也。 }\end{array}$ & 治各不同 & 可也。 & \\
\hline 五方 & 故東方者 & 西方者 & 北方者 & 南方者 & 中央者 \\
\hline $\begin{array}{c}1 . \\
\text { 地勢 }\end{array}$ & $\begin{array}{l}\text { 天地之所始 } \\
\text { 生也, 魚監 } \\
\text { 之地, 海濱 } \\
\text { 傍水, }\end{array}$ & $\begin{array}{l}\text { 金玉之域, } \\
\text { 沙石之處, } \\
\text { 天地之所收 } \\
\text { 引也。 }\end{array}$ & $\begin{array}{l}\text { 天地所始閉 } \\
\text { 藏之域也, } \\
\text { 其地高陵 } \\
\text { 居, 風寒冰 } \\
\text { 洌, }\end{array}$ & $\begin{array}{l}\text { 天地所長 } \\
\text { 養, 陽之所 } \\
\text { 盛處也, 其 } \\
\text { 地下, 水土 } \\
\text { 弱, 霧露之 } \\
\text { 所聚也, }\end{array}$ & $\begin{array}{l}\text { 其地平以 } \\
\text { 濕, 天地所 } \\
\text { 以生萬物也 } \\
\text { 衆, }\end{array}$ \\
\hline $\begin{array}{c}2 . \\
\text { 其民 } \\
\text { 風俗 }\end{array}$ & $\begin{array}{l}\text { 其民食魚而 } \\
\text { 嗜獻, 皆安 } \\
\text { 其處, 美其 } \\
\text { 食 }\end{array}$ & $\begin{array}{l}\text { 其民陵居而 } \\
\text { 多風, 水土 } \\
\text { 剛強, 其民 } \\
\text { 不衣而褐 } \\
\text { 薦, }\end{array}$ & $\begin{array}{l}\text { 其民樂野處 } \\
\text { 而乳食, }\end{array}$ & $\begin{array}{l}\text { 其民嗜酸而 } \\
\text { 食腑, }\end{array}$ & $\begin{array}{l}\text { 其民食雜而 } \\
\text { 不勞, }\end{array}$ \\
\hline $\begin{array}{c}3 . \\
\text { 體質 }\end{array}$ & $\begin{array}{l}\text { 魚者使人熱 } \\
\text { 中, 獻者勝 } \\
\text { 血, 故其民 } \\
\text { 皆黑色踈 } \\
\text { 理, }\end{array}$ & $\begin{array}{l}\text { 其民華食而 } \\
\text { 脂肥, 故邪 } \\
\text { 不能傷其形 } \\
\text { 體, }\end{array}$ & & $\begin{array}{l}\text { 故其民皆緻 } \\
\text { 理而赤色, }\end{array}$ & \\
\hline $\begin{array}{c}4 . \\
\text { 疾病 }\end{array}$ & $\begin{array}{l}\text { 其病皆為䬶 } \\
\text { 瘍 }\end{array}$ & $\begin{array}{l}\text { 其病生於 } \\
\text { 内, }\end{array}$ & $\begin{array}{l}\text { 藏寒生滿 } \\
\text { 病, }\end{array}$ & 其病攣廟, & $\begin{array}{l}\text { 故其病多瘘 } \\
\text { 厥寒熱, }\end{array}$ \\
\hline $\begin{array}{c}5 . \\
\text { 療法 }\end{array}$ & 其治宜砭石 & $\begin{array}{l}\text { 其治宜毒 } \\
\text { 藥, }\end{array}$ & $\begin{array}{l}\text { 其治宜负 } \\
\text { 燤, }\end{array}$ & $\begin{array}{l}\text { 其治宜微 } \\
\text { 銊, }\end{array}$ & $\begin{array}{l}\text { 其治宜導引 } \\
\text { 按蹻, }\end{array}$ \\
\hline $\begin{array}{c}6 . \\
\text { 療法 } \\
\text { 本源 }\end{array}$ & $\begin{array}{l}\text { 故砭石者, } \\
\text { 亦從東方 } \\
\text { 來。 }\end{array}$ & $\begin{array}{l}\text { 故毒藥者, } \\
\text { 亦從西方 } \\
\text { 來。 }\end{array}$ & $\begin{array}{l}\text { 故负炳者, } \\
\text { 亦從北方 } \\
\text { 來。 }\end{array}$ & $\begin{array}{l}\text { 故九鍼者, } \\
\text { 亦從方南 } \\
\text { 來。 }\end{array}$ & $\begin{array}{l}\text { 故導引按蹻 } \\
\text { 者, 亦從中 } \\
\text { 央出也。 }\end{array}$ \\
\hline 結論 & \multicolumn{5}{|c|}{$\begin{array}{l}\text { 故聖人雜合以治, 各得其所宜, 故治所以異而病皆愈者, 得病之情, 知治 } \\
\text { 之大體也。 }\end{array}$} \\
\hline
\end{tabular}

Fig. 4a. Inner Canon of the Yellow Emperor: Basic Questions

'On different methods being regionally appropriate' di 12, 1-5 jue.

the Inner Canon discussed fondness for salty or sour foods, and a tendency to eat fish, fermented foods, or cow's milk. In contrast to expressing a concern about the simplistic understanding of novice readers as did Wang Lun or the misuse of a famous formula for fevers as did Xue $\mathrm{Ji}$, the Inner Canon version emphasised the five regional origins of five types of therapy: 'stone needles' (bianshi 砭石) in the east, 'toxic medicinals' or 'potent drugs' (duyao 毒藥) in the 


\begin{tabular}{|c|c|c|c|c|c|}
\hline \multirow{2}{*}{$\begin{array}{l}\text { Prefatory } \\
\text { Question }\end{array}$} & \multicolumn{5}{|c|}{$\begin{array}{l}\text { The Yellow Emperor Asked: As for when physicians treat illnesses, why is it that they use different treatments for the same illness } \\
\text { [yet] cure all? Qi Bo responded: [Different] features of the land cause it to be so. }\end{array}$} \\
\hline & East & West & North & South & Central \\
\hline $\begin{array}{l}\text { l. } \\
\text { Land }\end{array}$ & $\begin{array}{l}\text { Thus the eastern region } \\
\text { is the place where heaven } \\
\text { and earth first bring } \\
\text { [things] to life. [It is] the } \\
\text { land of fish and salt } \\
\text { [where] ocean shores } \\
\text { meet water [ways]. }\end{array}$ & $\begin{array}{l}\text { The western region is } \\
\text { the territory of gold and } \\
\text { jade, the place of sand } \\
\text { and stones, where heaven } \\
\text { and earth bring in the } \\
\text { harvest. 'The people } \\
\text { here live in caves and } \\
\text { it is often windy; the } \\
\text { water and soil are hard } \\
\text { and strong. }\end{array}$ & $\begin{array}{l}\text { The northern region is } \\
\text { where heaven and earth } \\
\text { secure and store [things]. } \\
\text { The land is high, [there } \\
\text { are] cave dwellings, } \\
\text { wind, cold, ice, and } \\
\text { [bitter] cold. }\end{array}$ & $\begin{array}{l}\text { The southern region } \\
\text { is where heaven } \\
\text { and earth mature and } \\
\text { nourish [things] and } \\
\text { where yang [qi] is } \\
\text { abundant. The land is } \\
\text { low lying; water and } \\
\text { soils are weak. It is } \\
\text { where fogs and dews } \\
\text { assemble. }\end{array}$ & $\begin{array}{l}\text { The central region's land } \\
\text { is level and thereby } \\
\text { damp. It is where heaven } \\
\text { and earth engender the } \\
\text { myriad things. }\end{array}$ \\
\hline $\begin{array}{l}2 . \\
\text { Customs }\end{array}$ & $\begin{array}{l}\text { The people here eat } \\
\text { fish and favor salty } \\
\text { foods; all are peaceful } \\
\text { in their abodes and } \\
\text { appreciate their foods. }\end{array}$ & $\begin{array}{l}\text { The people here do not } \\
\text { wear [silks] but coarse } \\
\text { cloth and straw. }\end{array}$ & $\begin{array}{l}\text { The people here like to } \\
\text { reside in the wild and } \\
\text { consume milk. }\end{array}$ & $\begin{array}{l}\text { The people here favor } \\
\text { sour [foods] and eat } \\
\text { fermented [foods]. }\end{array}$ & $\begin{array}{l}\text { Numerous, the people } \\
\text { here eat diverse [foods] } \\
\text { and do not get fatigued } \\
\text { [i.e., from hard work]. }\end{array}$ \\
\hline \begin{tabular}{c|}
3. \\
Constitutions
\end{tabular} & $\begin{array}{l}\text { [Since] fish causes heat } \\
\text { within humans [and] } \\
\text { salt rules over Blood, } \\
\text { the people here all have } \\
\text { a dark complexion and } \\
\text { open [i.e., loosely } \\
\text { dispersed] pores. }\end{array}$ & $\begin{array}{l}\text { The people here have } \\
\text { plentiful foods and are } \\
\text { thus corpulent. }\end{array}$ & & $\begin{array}{l}\text { Therefore the people } \\
\text { here all have fine } \\
\text { [i.e., tightly dispersed] } \\
\text { pores and a reddish } \\
\text { complexion. }\end{array}$ & \\
\hline
\end{tabular}


Fig. 4b (cont.)

\begin{tabular}{|c|c|c|c|c|c|}
\hline 5 Regions & East & West & North & South & Central \\
\hline $\begin{array}{c}4 . \\
\text { Illnesses }\end{array}$ & 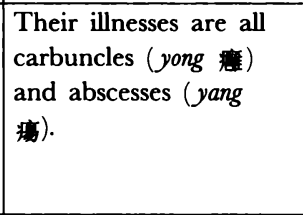 & $\begin{array}{l}\text { Therefore pathogenic } \\
{[q i] \text { cannot harm their }} \\
\text { bodies [so] their } \\
\text { illnesses arise from } \\
\text { within. }\end{array}$ & $\begin{array}{l}\text { Hidden [pathogenic] } \\
\text { cold [in the body] } \\
\text { gives rise to illnesses of } \\
\text { fullness (manbing 滿病). }\end{array}$ & $\begin{array}{l}\text { Their illnesses are } \\
\text { spasms (luan 摮) and } \\
\text { numbness in the trunk } \\
\text { and limbs ( } b i \text { 㿎). }\end{array}$ & $\begin{array}{l}\text { Their illnesses are often } \\
\text { paralysis (wei 瘘), } \\
\text { numbness or coldness in } \\
\text { the extremities (jue 片), } \\
\text { and cold or hot } \\
\text { [disorders]. }\end{array}$ \\
\hline $\begin{array}{c}5 . \\
\text { Treatments }\end{array}$ & $\begin{array}{l}\text { Their appropriate } \\
\text { treatment is stone } \\
\text { needles (bianshi 䂠石). }\end{array}$ & $\begin{array}{l}\text { Their appropriate } \\
\text { treatments are toxic } \\
\text { [i.e., potent] drugs } \\
\text { (duyao 毒藥). }\end{array}$ & $\begin{array}{l}\text { Their appropriate } \\
\text { treatment is moxibustion } \\
\text { and cauterization (jüuru } \\
\text { 负满). }\end{array}$ & $\begin{array}{l}\text { Their appropriate } \\
\text { treatment is needles } \\
\text { (zhen }) \text {. }\end{array}$ & $\begin{array}{l}\text { Their appropriate } \\
\text { treatment is guiding- } \\
\text { pulling (daoyin 覓引) } \\
\text { and massage (anqiao 按政). }\end{array}$ \\
\hline $\begin{array}{l}6 . \\
\text { Origin of } \\
\text { Treatments }\end{array}$ & $\begin{array}{l}\text { This is why stone } \\
\text { needles also came from } \\
\text { the eastern region. }\end{array}$ & $\begin{array}{l}\text { This is why toxic } \\
\text { drugs also came from } \\
\text { the western region. }\end{array}$ & $\begin{array}{l}\text { This is why moxibustion } \\
\text { and cauterization came } \\
\text { from the northern } \\
\text { region. }\end{array}$ & $\begin{array}{l}\text { This is why the nine } \\
\text { needles came from the } \\
\text { southern region. }\end{array}$ & $\begin{array}{l}\text { This is why guiding- } \\
\text { pulling and massage also } \\
\text { came from the central } \\
\text { region. }\end{array}$ \\
\hline Conch & \multicolumn{5}{|c|}{$\begin{array}{l}\text { Therefore, the sages combined the various [therapies] so as to treat each contracted [illness] according to what is appropriate [to it]. } \\
\text { Hence, as for cases of using different therapies and curing all the illnesses, this is because [they] grasped the circumstances of [each] } \\
\text { illness and understood the overall contours of therapy. }\end{array}$} \\
\hline
\end{tabular}

Fig. 4b. 'On different methods being regionally appropriate' (Yifa fangyi lun pian) di 12, 1-5 jie. Inner Canon of the Yellow Emperor: Basic Questions (Huangdi neijing: suwen, c. first century BCE). 
west, 'moxibustion' and 'cauterisation' (jiuruo 负炳) in the north, the 'nine needles' (juzzhen 九鍼) in the south, and 'guiding-pulling' (daoyin 導引) and 'pushing down-lifting up' or 'massage' (anqiao 按跨) in the centre.

In addition to noting that these regional designations followed the five phases system of correlations, Lu and Needham hypothesised that this ancient account of the origins of ancient therapies may have also acknowledged the confluence of bordering societies into 'a common Sinic stock' ${ }^{60}$ Whether or not their hypothesis holds, this passage nevertheless provided the earliest idioms for discussing regional variations in land, climate, customs, constitutions, and illnesses from then on within the Sinic cultural-political sphere.

Although the title 'On different methods being regionally appropriate' is the same in the two texts, neither Wang Lun nor Xue Ji mentioned the 'five regions' either in the essay of the same title or anywhere else in their published works. ${ }^{61}$ The rhetorical reference to the Inner Canon as the canonical authority in medicine did not mean that medical authors strictly adhered to or quoted the letter of the canon' though they certainly borrowed concepts and idioms established therein.

The most important dichotomy for the land that later physicians drew upon was between the high plateaus of the north and the low lying regions of the south; for the climate, the cold and winds of the north contrasted with the fogs and dews of the south. For constitutions, the dichotomy between open (loosely dispersed) pores (shuli 疏理) and fine (tightly dispersed) pores (zhili 緻理) continued as a relevant idiom to explain human variation despite the later irrelevance of the specific association with eastern and southern constitutions, respectively. In Xue Ji's response to Wang Lun's essay, for example, he contrasted the loose pores (couli shutong 腠理疏通) of those in the southeastern regions from those with tightly closed pores (couli zhimi 腠理緻密) in

${ }^{60} \mathrm{Lu}$ and Needham 1980 , pp. 1-2. They suggested that 'In this case, acupuncture would have been associated with the south-eastern quasi-Indonesia aquatic element, while moxa would have come down to join it from the northern quasi-Tungusic nomadic element, and the pharmaceutical influence would have come from the western Szechuanese and quasi-Tibetan element'.

${ }^{61}$ Leung 2002, pp. 171-2, has already clearly examined the change from the five regions model to the northwest-southeast model from the Han to the Ming dynasty. She argued that the same divergence indicated further refinement on the relationship between the environment and the human constitution in the writings of late-Ming physicians such as Wang Lun and Zhang Lu 張珞 (1617-1700). 
the northwestern regions. Xue Ji's dichotomy only maintained the correlation between eastern constitutions and loose pores and contradicted the correlation between southern constitutions and tight pores in the original Inner Canon version. The correlation between a preference for salting foods in the east and sour foods in the south bear no relation even to the five sapors-five regions associationsEast-sour, West-pungent, North-salty, South-bitter, and Central-sweetin other sections of the original Inner Canon: Basic Questions. ${ }^{62}$

Wang Lun was not the first medical scholar to refer to the title of the Inner Canon's 'On different methods being regionally appropriate' and yet largely ignore its specific content about the five regions and origins of the five therapies. In at least five medical texts published before his Enlightened Physicians, medical authors cited the same title from the Inner Canon to give a patina of ancient authority to their contemporary criticisms of clinical problems in medical practice they thought arose from regional variations in the environment, climate, and constitutions. ${ }^{63}$ Their citation of the title of the original Inner Canon essay on regionalism, in other words, was a useful resource for them to discuss tensions, fissures, and diversity more broadly in the contemporary literate medical sphere. They rarely quoted the Inner Canon original verbatim, however, because the five regions model that it summarised no longer corresponded with the social or political reality they experienced.

${ }^{62}$ See especially 'Essay on the genuine words of the Golden Casket' ( Jinkui zhenyan lun pian 金厝真言論篇) in Ren 1986, di 4, zhang 3, p. 17.

${ }^{63}$ A search of the phrase 'yifa fangyi' 異法方宜 (Different methods being regionally appropriate) in the Siku quanshu electronic database turned up the following five texts between the Huangdi neijing suwen and Xue Ji's Xueshi yian, which republished the Mingyi zazhu: Suwen rushi yunqi lun ao 素問入式運氣論奥 (Marvellous introductory remarks on the theory of the [five] circulatory phases and [six seasonal] $q i$ according to the Suwen), juan 3, 'Lun liubing di 28' 論六病第 28 (On six diseases \#28); Shanghan weizhi lun 傷寒微旨論 (On Cold Damage and profound purpose), juan 1, 'Zhibing suizheng jiaxian yaopian' 治病隨證加減藥篇 (Treatment of disease by increasing and decreasing drugs according to the pattern); Taiyiju zhuke chengwen ge 太醫居諸科程文 格 (The Imperial Medical Bureau's examination essay model [questions] in various disciplines), juan 1, 'Di er dao' 第二道 (Second issue); Puji fang 普淯方 (Formulas for General Benefit), juan 240, 'Jiaoqimen: yiqiu jiaoqi' 腳氣門: 一切腳氣 (Foot qi section: a type of foot $q$ ); $\Upsilon_{u j i}$ weiyi 玉機微義 (Subtle reasoning of the jade power [of the universe]), juan 14, 'Jiufa' 负法 (Moxibustion methods), and juan 23, 'Bian beifang jiaoqi suode zhi you' 辩北方腳氣所得之由 (Essay on the cause of obtaining northern foot qi). None of these citations of 'yifa fangyi quoted the same content of the original Suwen essay of the same title. 


\section{(3) On avoiding simplistic environmental determinism}

Wang Lun explicitly confronted medical regionalism again in the second essay titled 'If someone asked about the methods for treating disease of $\mathrm{Li}$ Gao and Zhu Zhenheng'. In a comparison of the contrasting therapeutic styles of two physicians, Li Gao (1180-1251) and Zhu Zhenheng (1281-1358), for instance, Wang called attention to misperceptions among his contemporaries of different therapeutic strategies between northern and southern physicians. His underlying point, however, cautioned his novice readers about following simplistic regional determinism in their medical practices. He began by questioning why some people thought that Li Gao's methods were only suited for the north whereas Zhu Zhenheng's treatments were only good for the south.

Nowadays some say that the methods of Dongyuan [Li Gao] are appropriate for use in the north and the methods of Danxi [Zhu Zhenheng] should be practised in the south. Why is this? This is because Dongyuan was a northern physician and Luo Qianfu 羅謙甫 [i.e., Luo Tianyi, c. 13th century] transmitted his methods so that they could become known in Jiang[su] and Zhe[jiang]. Danxi was a southern physician and Liu Zonghou [i.e., Liu Chun 劉純, c. 14th century] passed on his teachings so that they could be well known in Shaanxi. Suppose someone said that the [Divine Husbandman's] Materia Medica and the Inner Canon [of the Yellow Emperor], being teachings of the Divine Husbandman, Yellow Emperor, and Qi Bo, could only by applied in the north?64

Just because the ancients lived in the north, this did not make the Inner Canon a 'northern' medical text. Similarly, although Li Gao was a northern physician and Zhu Zhenheng practised in the south, their medical ideas were not limited to those regions. Their disciples, in fact, successfully transmitted their medical works outside of their native regions: Li Gao's disciple Luo Tianyi brought his work south to Jiangsu and Zhejiang in central China and Zhu Zhenheng's disciple Liu Chun introduced his work northwest to Shaanxi province. Wang concluded this opening section with a rhetorical question to which the obvious answer was no: No, the teachings of the divine sovereigns - the Divine Husbandman and the Yellow Emperor-are not regionally limited but rather universally valid. ${ }^{65}$ By extension, the

${ }^{64}$ Mingyi zazhu, juan 3, p. 106.

${ }^{65}$ On the largely early Han-dynasty idea of legendary sages as culture-givers of knowledge based on a universal standard - such as the Divine Husbandman and 
therapies of the northern doctor $\mathrm{Li} \mathrm{Gao}$ and the southern doctor Zhu Zhenheng are as universal.

In the following passage, Wang Lun succinctly challenged such simplistic regional determinism by citing the origin of such ideas in the Inner Canon. This time, he referred to the five regions model, which he did not mention in his first essay on 'Different methods being regionally appropriate'. ${ }^{66}$ To complicate the simplistic northsouth division of the opening sentence, Wang added the geographic distinctions of provinces - Shaanxi, Jiangsu, and Zhejiang when he mentioned the disciples Luo Tianyi and Liu Chun-and the regions of Jiang $\mathrm{Hu}$ and Lingnan - when he discussed dominant climatic factors.

As for the appropriateness of different treatments for the different illnesses that arise in the five regions, the Inner Canon's [essays on] 'On different methods being regionally appropriate' and the 'Great treatise on the five regularities of governance' discuss this in detail. For example, it is colder in the north, hotter in the south, damper in the region of lakes and rivers, and more miasmic in Lingnan. Wherever these types of $q i$ (i.e., Cold, Hot, Damp, and Miasmic) are prevalent, there will also be more of that kind of disorder; but this does not mean that of the northern disorders, there are none due to Heat, or that of the southern disorders, there are none due to Cold. As for treating cold disorders with hot [formulas] and treating hot disorders with cold [formulas], this principle is the same in all five regions, so how could it differ in the north and south?67

Although these provinces and regions did not fit easily into the ancient model of five regions, they did coincide well with contemporary Ming conceptions of geography. Despite regional prevalence in morbidity, the pathogenic factors - hot and cold - as well as the fevers and chills they caused, transcended the north and south division. The key point for the physician was to know when the regional climate was at play and when to make an exception for the individual

the Yellow Emperor - see the section on 'sovereigns as innovators' in Sivin 1995b, pp. 188-90.

66 Wang Lun did not refer to the same 'five regions' of the Inner Canon, but rather mentions the north 'beifang' 北方, south 'nanfang' 南方, Lingnan 领南, and Jiang $\mathrm{Hu}$ 江湖 and ignores the three other original regions - west 'xifang' 西方, east 'dongfang' 東方, and centre 'zhongyang' 中央. This example further supports the argument that when later medical authors refer to the Inner Canon's 'Yifa fangyi lun' chapter 12 from Basic Questions, they refer to the general concept of regional variation or biases in medical practices, but do not adhere closely, if at all, to the specific content of the original Basic Questions chapter.

67 Mingyi zazhu, juan 3, 106. 
patient. By arguing for more subtle diagnostic skills among physicians, Wang Lun portrayed himself as the impartial model to follow.

In the concluding section of this essay, Wang returned to the common misconception with which he introduced the essay, namely that Zhu Zhenheng's formulas were most appropriate for treating patients in the south and Li Gao's were best suited for the north. Having placed himself in the textual lineage of Zhu Zhenheng by structuring his Enlightened Physicians largely around Zhu's doctrines, he sought to give his predecessor proper credit in medical history as someone who penetrated the mysteries of the Inner Canon and realised that the Song Imperial Formulary was biased toward illnesses due to damp and hot pathogens.

However, in the human viscera, Fire resides in two places; of the six climatic $q i$ of heaven, Hot resides in three or half [of them]. Thus of all the illnesses under heaven, Hot is more and Cold less [a significant factor]. Examine the Inner Canon's section on 'disease extremities' of the 'Major essay on arriving at the genuine essentials'. Furthermore, it is even more common that Damp and Hot [factors] combine with Fire to cause illnesses. From Taipu's [i.e., Wang Bing 王冰 (c. eighth century)] commentary [on the Inner Canon], up to the Bureau Formulary (Jufang 局方) ${ }^{68}$ there was a bias toward using Damp and Hot medicines. Thus Danxi [i.e., Zhu Zhenheng] uncovered and penetrated the mysteries of the Inner Canon, examined the bias in the Imperial Formulary toward illnesses due to Damp and Hot [factors] combined with Fire, and supplemented what his predecessors had left incomplete. Those who followed did not understand this and seeing that he often used Poria cocos (fuling 苻苓 'China-root'), Lotus (lian 連), Jasmine (zhi 柜), and Phellodendron (huangbai 黄柏 or 'Cork-tree'), types of bitter and cold drugs, [thought] that this was because they were better suited for the south. How superficial! ${ }^{69}$

Zhu's frequent use of bitter and cold medicines in his formulas was not because he was a southern physician, but rather because his predecessors had not fully developed the use of these types of drugs. Zhu had the insight to develop what his predecessors had left incomplete and which he alone was able to make whole. By aligning himself with Zhu Zhenheng's teaching, Wang Lun presented himself as the inheritor of the most comprehensive medical knowledge to date.

${ }_{68}$ The full title was originally to the northern-Song imperial medical bureau's publication, Formulary of the pharmacy service for benefiting the people in an era of great peace (Taiping huimin heji jufang 太平惠民和劑局方, early 12th century). Goldschmidt 2005, p. 80.

${ }^{69}$ Ibid. 
Rhetorically, Wang employed the facile regional conception of the northern formulas of $\mathrm{Li}$ Gao for northerners and the southern formulas of Zhu Zhenheng for southerners to assert the opposite; namely, the universal validity of his Enlightened Physicians for all potential readers throughout the empire, north and south.

\section{Northwest-southeast and northern-southern in a Ming medical compendium}

Neither Wang Lun nor Xue Ji specifically cited the earlier geographic concept 'Heaven is insufficient in the northwest; earth is incomplete in the southwest' to explain either regional or corporal differences, though they both accepted the geo-climatic northwest-southeast polarity based on it. Both meanings of this concept, however, appear in another mid-sixteenth-century text titled the Compendium of the Medical Tradition, Past and Present (Gujin yitong daquan 古今醫統大全, preface 1556) edited by Xu Chunfu 徐春甫 (1520?-1596?). He was born into a hereditary family of officials in Anhui province, but he favoured medicine and ended up becoming an imperial physician in the Ming Imperial Medical Academy. ${ }^{70} \mathrm{Xu}$ Chunfu published this Compendium five years after Xue Ji's commentary on the Enlightened Physicians (preface 1551). They may have even crossed paths in the Imperial Medical Academy. In a 'Genuine guide to acupuncture and moxibustion' (zhenjiu zhenzhi 針尒直指), Xu Chunfu quoted verbatim the entire passage of the Inner Canon's 'On different methods being regionally appropriate' to provide the regional origin story of acupuncture and moxibustion. ${ }^{71}$

Zhu Zhenheng's medical regionalism according to Xu Chunfu's Compendium

The use of the concept 'Heaven is insufficient in the northwest; earth is incomplete in the southwest' to explain regional differences in climate and constitutions appeared only in an essay titled 'Medicines differ just as the customs of the four regions differ' (sifang fengtu butong, fuyao yi yi 四方風土不同 夫藥亦異). Xu Chunfu attributed this passage

${ }^{70}$ Li Yun 1988, p. 743.

71 Gujin yitong daquan 1998, juan 7, p. 446. 
to Zhu Zhenheng, although an essay by this name could not be found in any of his writings. The closest parallels are found in Dai Liang's biography of Zhu Zhenheng titled 'Danxi weng zhuan' 丹溪翁專 in which he also cited the geo-climatic polarity that 'heaven is insufficient in the northwest; and earth is incomplete in the southeast' in reference to Zhu's medical thought on regionalism. ${ }^{72}$ Zhu Zhenheng discussed regional variation elsewhere in his work, however, which substantiates why $\mathrm{Xu}$ Chunfu and his readers associated this medical regionalism so directly with him. ${ }^{73}$ Still the debate expressed in the following passage attributed to Zhu Zhenheng belongs more to $\mathrm{Xu}$ Chunfu and sixteenth-century Ming medicine than to Zhu Zhenheng and medicine in the Yuan dynasty. The passage opened with the following statement:

Danxi said: the northwest region is windier and colder, and so those who suffer from external afflictions are greater. The southeast region is fundamentally low lying and damp, therefore those who suffer from Damp and Hot [pathogenic factors] are numerous. Since the northern region has high plateaus, heaven is insufficient in the northwest, resulting in greater windiness. [Since] the southern region is low lying, earth is incomplete in the southeast, resulting in more dampness. According to the local conditions, each has its irregularity; that which gives rise illnesses, mostly follows the locale with which it comes in contact. $^{74}$

Up to this point in the passage, the concept of the tilting northwestsoutheast axis does not differ significantly from one of its sources in the 'Major essay on the regulations of the five regularities' (Wuchang zheng dalun 五常政大論) of the Inner Canon of the Yellow Emperor: Basic Questions. The rest of the passage, however, diverged from the Inner Canon original by emphasising northern and southern (not northwestern and southeastern) differences in climate, bodily constitutions, eating and living habits, illnesses, and appropriate therapies.

The passage attributed to Zhu Zhenheng used the same idioms of 'powerful and robust' (xiongzhuang 雄壯) and 'soft and fragile' (roucui 柔脆) that Dai Liang used to distinguish northern and southern constitutions in his preface to Zhu Bishan. The most striking parallel to these idioms outside of medicine can be found in the commentary

${ }^{72}$ Danxi yiji 1995, Danxi xinfa 丹溪心法, juan 5, p. 480. Jiuling shanfang ji, juan 10.

${ }^{73}$ Danxi yiji 1995, Jufang fahui 局方發揮, pp. 47, 50; Danxi xinfa, pp. 196, 200, 209, 215.

74 Gujin yitong daquan 1998, juan 3, p. 198. 
on northern and southern differences in musical styles of the lateMing scholar Zhang Qi 張琦 (c. late 16th to early 17 th century). He used the same terms of a 'powerful and robust' quality in northern music to contrast with the 'soft and fragile' (roucui 柔脆) quality of southern music. Northern music is more martial, presumably because of its clanging instruments and percussion, whereas southern music is softer, clearer, and sharper, implicitly because it relies on strings and flutes. ${ }^{75}$ Whether describing corporeal or musical differences, both authors favoured northern qualities over southern ones.

The following statement of northern and southern differences in drug therapies attributed to Zhu Zhenheng suggests why some people during the sixteenth century thought that his therapeutic methods were best suited to southern patients:

Physicians must decided on a treatment according to the season and distinguish what is appropriate according to the land. Treating northern disorders, it is appropriate to consider attacking [formulas] to strike down the external pathogenic (xie 邪) $[q i]$ as the most common [treatment]; as for treating southern illnesses, it is appropriate to consider protecting [formulas] to nourish internal $q i$ as the basic [treatment]. Why is this so? ${ }^{76}$

Attacking external pathogenic xieqi frequently covered most northern diseases and protecting and nourishing the patient's internal $q i$ usually best treated southern diseases. The essay goes on to say that the weaker constitutions, looser pores, and indulgent diet of people in the southeast, made them too weak to bear the drastic purgatives commonly prescribed in the north. Patients in the northwest, conversely could handle purgatives because they had strong constitutions, ate ordinary food, and lived simply. The structure, argument, and specific examples in this passage, in fact, directly relate back to Dai Liang's account of his interactions with the Suzhou doctor Zhu Bishan. ${ }^{77} \mathrm{Xu}$ Chunfu appears to have taken some of Dai Liang's comments about Zhu Bishan and wove them into this passage on medical regionalism attributed to Zhu Zhenheng.

${ }^{75}$ Wusao hebian, 'Zuöia yuping' 作家偶評 3ab. I thank Katy Carlitz for showing me these citations on late-Ming views of northern and southern musical styles. For more detailed distinctions between northern and southern musical styles and a statement that they only diverged in the Yuan dynasty, see Yuanqu xuan, preface lab.

${ }^{76}$ Ibid.

77 Jiuling shanfang $\ddot{j}$, juan 13. 
Despite regional prevalence in constitutions - repletion of $q i$ in the north and depletion of $q i$ in the south - the essay concluded that this could not be the case for everyone in each region. It made a point comparable to the one Wang Lun made when he wrote that just because the climate in the north is colder and the southern climate is hotter, that general pattern should not lead one to conclude simplistically that no illnesses are due to heat in the north or none are due to cold in the south.

Both Wang Lun and Xu Chunfu cited these examples of medical regionalism in a comparable way. They argued that while the educated physician should understand these regional variations, he must not be rigid in his practice or biased one way or the other. $\mathrm{Xu}$ Chunfu attributed this essay to Zhu Zhenheng, perhaps because its central concern about regional variation remained the serious 'offence of a biased perspective' (yipian zhi bi-偏之弊) in medicine. Zhu Zhenheng admonished learned doctors to consider the individual patient's condition and determine a treatment accordingly. Similar to Wang Lun's concluding statement on Zhu Zhenheng, Xu Chunfu also presented Zhu Zhenheng through this citation as the type of impartial and unbiased physician he expected readers of the Compendium both to emulate and ideally become themselves. These two elite physicians of the literate sector of classical medicine created an unbiased persona in their medical primer and compendium, respectively, in response to the polarising tendencies of northern-southern medical regionalism among their contemporary competitors and potential critics.

\section{Li Zhongzi and late-Ming medical regionalism}

Medical regionalism is useful for the historian as a lens into what Ming physicians thought was 'askew' in human society and problematic in medical practice. Li Zhongzi 李中梓 (1588-1655), the author of the influential late-Ming medical primer, Required Readings for Physicians (of the Orthodox) Lineage (Yizong bidu 醫宗必讀, 1635), offered the most revealing path back to these issues. Among the Ming medical authors discussed, he wrote the most extensive discussion of medical regionalism in two separate essays. One from Required Readings and one from a book he published seven years later titled On the Subtleties of Nourishing Life, Revised and Supplemented ([Shan bu] Yisheng weilun 刪補頣生 微論, 1642). 
Li Zhongzi came from an elite family of officials who lived in Jiangsu province in Yunjian, now modern-day Songjiang prefecture, just southwest of Shanghai. Li was the son of Li Shanggun 李尚衰 ( $\ddot{j} n-$ shi 1590) who in 1593 was promoted to an official position as a secretary in the Ministry of War. Li Zhongzi succeeded far enough along the examination system to become a Government Student. He had also earned himself a literary reputation. According to his own account, because he had fallen ill himself, he began to study the Han medical canons and the works of the 'Four medical masters' (sidajia 四大家), namely Zhang Ji 張機 (c. 196-220), Liu Wansu, Li Gao, and Zhu Zhenheng. ${ }^{78}$ These were the same physicians Wang Lun promoted as essential reading in the opening essay of his Enlightened Physicians. ${ }^{79}$

In Required Readings, Li discussed from several angles the diversity of medical doctrines and practices that he found in the medical corpus. In an essay 'On the four masters' (Sidajia lun), he explained this diversity in part as the result of a history of supplementing and improving upon one's predecessors similar to Wang Lun's view of medical history. ${ }^{80} \mathrm{Li}$ argued, however, that such differences were also due to marked contrasts in economic status, eating habits, and dwellings. His new emphasis on constitutional contrasts between the wealthy and noble, on one side, and the poor and ignoble, on the other, contrasted with Xue Ji's earlier geo-climatic explanations of northern and southern constitutions. Over the course of the roughly 75 years that separated Xue Ji and Li Zhongzi, Ming China experienced an economic and commercial transformation that markedly increased the distance between the wealthy and the poor. ${ }^{81}$ Li Zhongzi's new deployment of economic status as a marker of corporeal as well as quality of housing, lifestyle behaviours, and eating habits resonated well with the changes in society and the economy his readers would have experienced.

\footnotetext{
${ }^{78}$ See Bao Laifa et al. (eds) 1999, vol. 1, pp. 789-92. See also Li Yun 1988, pp. $272-3$.

${ }^{79}$ Mingyi zazhu, juan 1, pp. 1-2.

80 Yizong bidu, juan 1, p. 80. Unschuld 1985, 203, also noted Li Zhongzi's defense of these authors against charges of one-sideness.

${ }^{81}$ See especially 'Summer: The Last Century (1550-1644)' in Brook 1998, pp. 153-237.
} 


\section{(1) On regional and class differences in human constitutions}

In addition to this general thinning of primordial $q i$ among all humans, in the second essay $\mathrm{Li}$ described differences in medical practice in terms of economic status related to the same northern and southern cultural distinctions Dai Liang first mentioned in the fourteenth century. In the essay 'On the treatments for the wealthy and the poor not being the same' (Fugui pinjian zhibing you bie lun 富貴貧 賤治病有別論), $\mathrm{Li}$ argued that people from opposite class statuses had such significantly different body types that they required separate kinds of medical treatments. ${ }^{82}$ To illustrate his point, $\mathrm{Li}$ used an example of two physicians who, like Li Gao and Zhu Zhenheng in Wang Lun's essay, represented northern and southern regional styles of medicine.

Li compared the northern Jin-dynasty physician Zhang Congzheng 張從正 (1156-1228) and the southern mid-Ming doctor Xue Ji, the commentator and publisher of Wang Lun's Enlightened Physicians. Both were well known by Li's time for having established different therapeutic strategies and founded opposite currents of thought in medical practice. Zhang Congzheng was considered the founder of the 'Attack and purge current of learning' (gongxia pai 攻下派) because of his emphasis on descending prescriptions and purgatives. Xue Ji was considered to be the representative of the 'Warming and restoring current of learning' (wenbu pai 溫補派) because of his advocacy of warming prescriptions and restorative tonics.

Having read Zhang Zihe's [i.e., Zhang Congzheng] Confucian's Serve Their Kin, the drugs he used are only attacking (dagong 大攻) and cutting down (dafa 大伐) [i.e., drastic purgatives] [yet] toward [treating] disease [he was] miraculous. And having read Xue Lizhai's [i.e., Xue Ji] Sixteen Kinds, the drugs he used are only warming (dawen 大溫) and restoring (dabu 大補) [yet] toward [treating] diseases [he was] also miraculous. How could the use of drugs between these two men be opposite and yet both be equally effective? ${ }^{83}$

$\mathrm{Li}$ quoted from the Inner Canon: Basic Questions chapter 78 titled 'On evidence of the four lapses' (Wei si shi lun 徵四失論) about differences between the poor and the wealthy, the noble and the ignoble:

[If one] does not suit [formulas] according to [where] the wealthy and noble (fugui 富貴) and the poor and ignoble (pinjian 貧賤) dwell, the

${ }^{82}$ rizong bidu, juan 1, p. 81.

${ }^{83}$ Ibid. 
thickness of [their] sitting [mats?], the hotness or coldness of [their] bodies; [If one] does not adjust what is appropriate [for them] to drink and eat, cannot differentiate the brave from the meek, and cannot understand the comparison, [then they have] completely confused themselves and are insufficiently enlightened. ${ }^{84}$

Similar to Dai Liang's representative passage already quoted, $\mathrm{Li}$ extended the class distinctions to corporeal ones by comparing how the different foods and dwellings of the wealthy and the poor contributed to their contrasting constitutions and susceptibility to external pathogens.

In general, the wealthy and noble labor their minds and the poor and ignoble labor their bodies. The wealthy and noble feed themselves rich foods and grains; the poor and ignoble fill themselves with sprouts and beans. The wealthy and noble have winding buildings with broad hallways; the poor and ignoble have hatched huts in poor alleyways.

Those who labor their minds, have a depleted center, weak sinews, and brittle bones. Those who labor their bodies, have full centers, strong bones, and powerful sinews. Those who feed themselves on rich fare always have delicate organ systems. Those who fill themselves on sprouts and beans always have strong organ systems. Those who live in winding buildings with broad hallways have loose pores so that the six pathogenic factors can easily reside [in their bodies]. Those who live in thatched huts in alleyways have tight pores so that the external pathogenic factors have a hard time getting [into their bodies].

Thus, the maladies of the wealthy and noble are well suited to [prescriptions] that restore the upright (zheng) [ $q i$ that has been depleted] and the maladies of the poor and ignoble will benefit from [prescriptions] that attack the deviant (xie) [qi that has invaded their bodies]. ${ }^{85}$

$\mathrm{Li}$ argued that Zhang Congzheng emphasised purgative drug therapy because he was treating commoners who worked the land with their hands. Their firm visceral systems and tight pores closed their bodies to external attack. Because they rarely weakened from within, when they fell ill it was most often due to external factors such as pathogenic Wind and Cold that had passed through their bodily defences. Strong acting purgatives that attacked these external factors were the best way to expel these climatic pathogens from the bodies

${ }^{84}$ The original text ends with the following conclusion ' $\mathrm{Ci}$ ' zhi zhi san shi yi' 此治之三失矣 (The three errors of this treatment). See 'Wei sishi lun' 徵四失論 (On evidence of the four errors, essay \#78), in Ren 1986, di 78, p. 249.

85 Yizong bidu, juan 1, p. 81. 
of his northern patients. By contrast, Li explained that Xue Ji favoured drugs with a warming and replenishing effect because his southern patients were wealthier and their more luxurious lives had weakened and softened their bodies. Their pores were loose, their bodies vulnerable to external attack, and their inner $q i$ in need of strengthening. For these reasons, they required the restorative prescriptions Xue Ji prescribed to strengthen their bodies. Unlike their northern counterparts, their bodies could not withstand drastic purgatives. Li related the contrasts in therapeutic strategies to the differences in economic status, diet, and quality of life of the patients the doctors Zhang and Xue saw most frequently in their medical practices:

The patients Zhang Congzheng cured were poor and ignoble so they could withstand his drastic purgatives. The patients Xue Ji cured were mainly the wealthy and noble so they were well suited to his restoratives. How in Zhang Congzheng's entire life could it be the case that not one restorative prescription was effective? How in Xue Ji's entire life could it be the case that not one purgative prescription was effective? It is just that when they wrote books and established their perspectives, they simply did not happen to mention these cases.

There are those who say that [because] Zhang Congzheng was northern, it was suitable to act this way and since Xue Ji was southern it was appropriate for him to act in the way he did. This is an outsider's perspective. Even though there were poor and ignoble families for whom it was best to use restoratives, it is just [the case that for Zhang Congzheng] there were more cases requiring purgatives and less requiring restoratives. Even though there were wealthy and noble families for whom [sometimes] it was also best to use purgatives, it is just [the case that for Xue Ji] there were fewer cases requiring purgatives and more requiring restoratives.

In these cases, one ought to take what is appropriate to the region as a distinguishing [characteristic] and what is the natural endowment of the person as a differentiating [factor]. As a base line, determine whether the person is in his prime or elderly, whether depleted or full. Do not be stuck on the one approach regarding the person's residence and diet and determine treatment only on those two bases. ${ }^{86}$

The main lesson to be learned from this discussion of human variation is not that these economic and climatic differences determined a patient's illness, but rather that they were stereotypical and could well lead the physician astray. Similar to Wang Lun and Xu Chunfu

${ }^{86}$ Yizong bidu, juan 1, p. 81. 
earlier, Li Zhongzi used medical regionalism to criticise over-simplified medical principles and biased approaches to medical care. Comparable to how Wang Lun corrected what he thought was a popular misconception of Zhu Zhenheng's writings as only for the south, $\mathrm{Li}$ argued that the physicians Zhang Congzheng and Xue Ji were not regionally biased or partial, but rather had finely adapted their treatments to the needs of their poorer and wealthier patients, respectively. He too constructed a persona of the unbiased literate physician in response to accusations circulating in public of the regional partiality of those physicians he considered his worthy predecessors.

\section{(2) Li Zhongzi on winds and soils and the five regions}

In his second book On the Subtleties of Nourishing Life, Li devoted one long essay on regional differences titled 'On locality' (fangtu lun 方土論). In contrast to most of his predecessors, Li closely followed the structure of the Inner Canon of the Yellow Emperor essay on 'On different methods being regionally suitable' ${ }^{87} \mathrm{I}$ have reproduced a full translation of the text in the figure below. ${ }^{88}$ [See Figure 5b]. The most obvious innovation to the original Inner Canon essay is integration of the five phases in the opening passages for each region: Li added the five phases, five seasons, and five climatic configurations of $q i$ under each category. Li Zhongzi's version of the Inner Canon's 'On different methods being regionally appropriate' differentiated the ancient five regions of the Former Han dynasty into commonly known provincial and regional names of the Ming dynasty: the east now became Southern Zhi (i.e., Jiangsu, centred around Nanjing the former capital of the Ming), Zhejiang, Shandong, and Fujian; the west comprised Shaanxi and Sichuan; the north was now Shanxi and Northern Zhi (i.e., Hebei, centred around Beijing, the capital of the Ming); the south included Jiangxi, Guangdong, Yunnan, and Guizhou;

${ }^{87}$ The exception is Zhang Jiebin 張介賓(1563-1640) in his Classified Canon (Lei jing 類經, 1624), published just two decades earlier. He wrote a lengthy commentary on the Inner Canon: Basic Questions essay 'Yifa fangyi lun' that elaborated the differences of the original five regions from the Former-Han dynasty version. Zhang Jiebin's commentary, however, did not revise or restructure the original essay as $\mathrm{Li}$ Zhongzi significantly did. See Lei jing, juan 12, pp. 199-200.

${ }_{88}$ [Shan bu] Yisheng weilun, juan 2, pp. 694-5. The bold characters in slightly larger font size are those that $\mathrm{Li}$ added to the original Inner Canon essay. The parentheses indicate characters and phrases from the original text that Li left out in his version. 
and finally, the central region encompassed Henan and Hunan. Li translated the abstract five regions into concrete administrative boundaries that any Ming reader would recognise; he rhetorically realigned the ancient symbolic system with the current social realm of the Ming body politic. Li's version integrated the five phases doctrine, which did not exist in the original Inner Canon essay, and mapped it onto the current Ming empire his readers would comprehend.

Resuming the structure of the Inner Canon essay, Li Zhongzi proceeded with a description of the dominant types of food people ate in each region and basic differences in their lifestyles. The chart of his revisions reveals several obvious asymmetries. In the section of the essay on bodily constitutions for each region, for instance, $\mathrm{Li}$ added the most commentary on the southern and eastern regions. For the bodily constitutions of northerners, the original Inner Canon essay said nothing nor did Li Zhongzi have anything to add. The characteristics of having full yang $q i$ and resistance to external invasion that later became associated with the 'northern' constitution, were originally attributed to the 'western' constitution both in the Inner Canon essay and again in Li's revision. Li added only a statement that the dominant illnesses in the north are due to being struck by cold. This lack of further detail on the northern regions compared to the detail on the southern and eastern regions suggests that his medical experience and priorities were also regionally focused in the southeast where he lived and practised medicine.

$\mathrm{Li}$ returned to the five phases in his comments on regional illnesses and new statements on the rationale for herbal formulas for each region: in the east, the physician should prescribe formulas that increase the foundation of Earth twofold in order to control the pathogenic Wind; in the west, strong attacking formulas were the most appropriate therapy, even though they could be deadly; in the north, since most illnesses were caused by cold, it was appropriate to increase the Fire source in order to diminish the concealed yin [i.e., pathogenic cold]; in the south, it was appropriate to take Water as the ruler in order to control the brilliance of yang $q i$; and in the centre, one should give formulas that assist the Wood phase as the ruler in order to control the pathogenic Earth phase in the body. Instead of expressing anxiety about a more indulgent southern lifestyle in contrast to a more frugal restrained northern one, however, he blamed excessive emotions, foods, and sexual relations for the illnesses of those who lived in the western region of China. Li Zhongzi 


\begin{tabular}{|c|c|c|c|c|c|}
\hline 引言 & 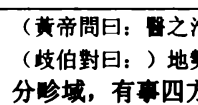 & $\begin{array}{l}\text { 也，）盖的一病 } \\
\text { 然也。五方之朱 } \\
\text { 男子之常，奈 }\end{array}$ & 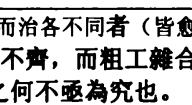 & $\begin{array}{l}\text { 也。) } \\
\text { 治, 豈知大 }\end{array}$ & 㸔茩生者, 不 \\
\hline 五方 & 東方 (者) 之域 & 西方 (者) 之域 & 北（者）之域 & 南方（者）之域 & 中央（者）之域 \\
\hline $\begin{array}{l}\text { 明朝 } \\
\text { 省 }\end{array}$ & $\begin{array}{l}\text { 今之南直浙江, } \\
\text { 山東, 楅建是 } \\
\text { 也。 }\end{array}$ & $\begin{array}{l}\text { 今之㚘西, 四川 } \\
\text { 是也。 }\end{array}$ & $\begin{array}{l}\text { 今之北直, 山西 } \\
\text { 是也。 }\end{array}$ & $\begin{array}{l}\text { 今之江西, 雨 } \\
\text { 席, 弿, 是 } \\
\text { 也。 }\end{array}$ & $\begin{array}{l}\text { 今之河南, 湖, } \\
\text { 庴是也。 }\end{array}$ \\
\hline 五行 & 于象為木, & 于象為金 & 于累為水 & 于累為火 & 于爱為土 \\
\hline 五時 & 于時為春, & 于時為秋, & 于時為冬, & 于時為文, & 于時為長夏 \\
\hline 1 地筫 & 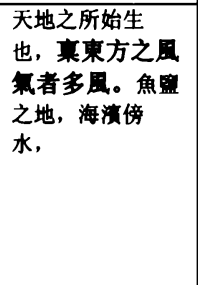 & 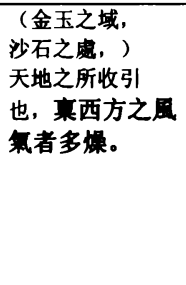 & 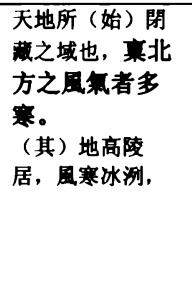 & 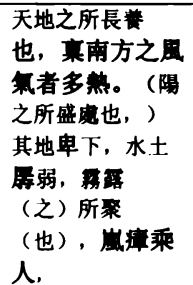 & 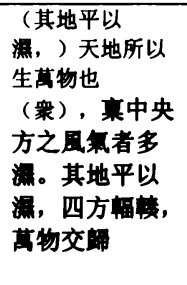 \\
\hline $\begin{array}{l}2 . \\
\text { 其民 } \\
\text { 風俗 }\end{array}$ & 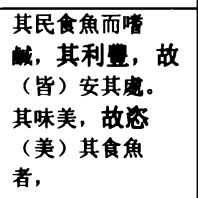 & 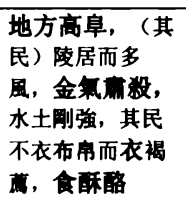 & $\begin{array}{l}\text { 其民樂野虎 } \\
\text { 而乳食, }\end{array}$ & $\begin{array}{l}\text { 其民整酸 (而) } \\
\text { 食 (朋) 不芬 } \\
\text { 香, 檅盛之虎 }\end{array}$ & $\begin{array}{l}\text { (其) 故民食雜 } \\
\text { 而不勞, }\end{array}$ \\
\hline 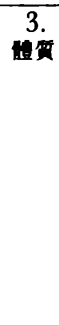 & 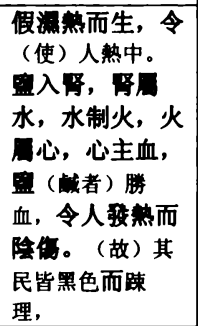 & 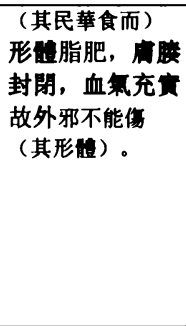 & & 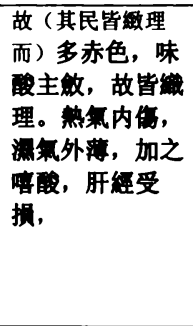 & 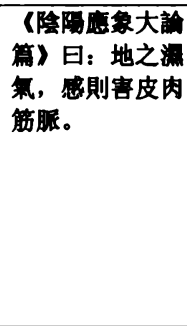 \\
\hline 4. & 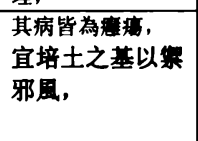 & 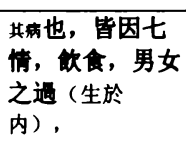 & 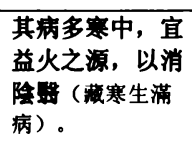 & 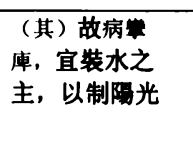 & 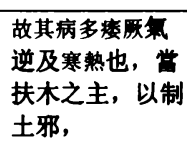 \\
\hline 遥法 & 其治宜砭石 & $\begin{array}{l}\text { 其治宜毒苜峻 } \\
\text { 攻，可使逍已， }\end{array}$ & 其治宜负燤, & 其治宜微鐵， & 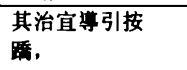 \\
\hline $\begin{array}{c}6 . \\
\text { 遵法 } \\
\text { 本源 }\end{array}$ & $\begin{array}{l}\text { 敬䂦石者, } \\
\text { 亦從東方來。 }\end{array}$ & $\begin{array}{l}\text { 敬青芼者, } \\
\text { 亦從西方來。 }\end{array}$ & $\begin{array}{l}\text { 故负茄者, 亦從 } \\
\text { 北方來。 }\end{array}$ & $\begin{array}{l}\text { 故九墭者, 亦從 } \\
\text { 方南來。 }\end{array}$ & $\begin{array}{l}\text { 故算引按活者, } \\
\text { 亦從中央出也。 }\end{array}$ \\
\hline 結諭 & \multicolumn{5}{|c|}{ 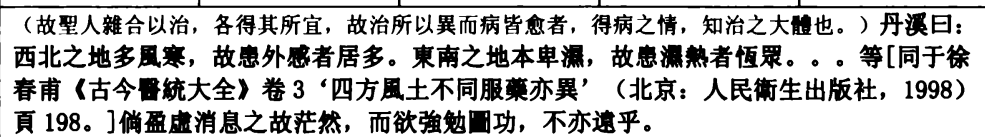 } \\
\hline
\end{tabular}

Fig. 5a. On the Subtleties of Nourishing Life, Revised and Supplemented [Shan bu] Yisheng weilun, juan 2, 'On Locality' 


\begin{tabular}{|c|c|c|c|c|c|}
\hline $\begin{array}{l}\text { Prefatory } \\
\text { Question }\end{array}$ & \multicolumn{5}{|c|}{$\begin{array}{l}\text { (The Yellow Emperor asked: As for when physicians treat illnesses,) why is it that they use different treatments for the same illness, } \\
\text { ([yet] cure all)? } \\
\text { (Qi Bo responded:) [Different] features of the land cause it to be so. The } q i \text { of the five regions is not uniform, thus the coarse } \\
\text { labor and various [therapies were] combined together in order to treat [illnesses]; how could [one] understand the } \\
\text { overall contours [of these therapies]? Those who have lived a long life and turned grey did not distinguish boundaries, } \\
\text { [as for] engagement with the four regions and the constants of man, how could one not study them to their limit? }\end{array}$} \\
\hline 5 Regions & East & West & North & South & Central \\
\hline $\begin{array}{l}5 \text { Regions } \\
\text { Provinces }\end{array}$ & $\begin{array}{c}\text { The eastern region, } \\
\text { today is Southern Zhi } \\
\text { (Nanjing and environs), } \\
\text { Zhejiang, Shandong, } \\
\text { and Fujian. }\end{array}$ & $\begin{array}{l}\text { The western region } \\
\text { today is Shaanxi } \\
\text { and Sichuan. }\end{array}$ & $\begin{array}{l}\text { The northern region } \\
\text { today is Northern Zhi } \\
\text { (Beijing and environs) } \\
\text { and Shanxi. }\end{array}$ & $\begin{array}{l}\text { The southern region } \\
\text { today is Jiangxi, } \\
\text { Guangdong and } \\
\text { Guangxi, Yunnan, } \\
\text { and Guizhou. }\end{array}$ & $\begin{array}{l}\text { The central region } \\
\text { today is Henan, } \\
\text { Hunan, and Hubei. }\end{array}$ \\
\hline 5 Phases & Its image is Wood & Its image is Metal & Its image is Water & Its image is Fire & Its image is Earth \\
\hline 5 Seasons & Its season is spring & Its season is autumn & Its season is winter & $\begin{array}{l}\text { Its season is } \\
\text { summer }\end{array}$ & $\begin{array}{c}\text { Its season is high } \\
\text { summer }\end{array}$ \\
\hline $\begin{array}{c}1 . \\
\text { Land }\end{array}$ & $\begin{array}{l}\text { Thus the eastern region } \\
\text { is) the place where } \\
\text { heaven and earth first } \\
\text { bring [things] to life. } \\
\text { Those who encounter } \\
\text { the wind } q i \text { of the } \\
\text { eastern region often } \\
\text { [catch] wind } \\
\text { [disorders]. [It is] the } \\
\text { land of fish and salt } \\
\text { [where] ocean shores } \\
\text { meet water [ways]. }\end{array}$ & $\begin{array}{l}\text { (The western region is } \\
\text { the territory of gold and } \\
\text { jade, the place of sand } \\
\text { and stones,) where heaven } \\
\text { and earth bring in the } \\
\text { harvest. Those who } \\
\text { encounter the wind qi } \\
\text { of the western region } \\
\text { often [catch] dryness } \\
\text { [disorders]. The land } \\
\text { has high plateaus ('The } \\
\text { people) here live in caves } \\
\text { and it is often windy; the } \\
\text { metal qi is severe and } \\
\text { deadly; the water and } \\
\text { soil are hard and strong. }\end{array}$ & $\begin{array}{l}\text { The northern region is } \\
\text { where heaven and earth } \\
\text { secure and store [things]. } \\
\text { Those who encounter } \\
\text { the wind qi of the } \\
\text { northern region often } \\
\text { [catch] cold } \\
\text { [disorders]. The land } \\
\text { is high, [there are] cave } \\
\text { dwellings, wind, cold, } \\
\text { ice, and [bitter] cold. }\end{array}$ & $\begin{array}{l}\text { The southern region is } \\
\text { where heaven and earth } \\
\text { mature and nourish } \\
\text { [things]. Those who } \\
\text { encounter the wind } \\
\text { qi of the southern } \\
\text { region often [catch] } \\
\text { hot [disorders]. (and } \\
\text { where yang [qi] is } \\
\text { abundant.) The land is } \\
\text { low lying; water and } \\
\text { soils are weak. It is } \\
\text { where fogs and dews } \\
\text { assemble. Vaporous } \\
\text { miasmas overpower } \\
\text { people. }\end{array}$ & $\begin{array}{l}\text { The central region's } \\
\text { land is level and } \\
\text { thereby damp. It is } \\
\text { where heaven and earth } \\
\text { engender the myriad } \\
\text { things. Those who } \\
\text { encounter the wind } \\
\text { qi of the central } \\
\text { region often [catch] } \\
\text { damp [disorders]. Its } \\
\text { land is level with } \\
\text { moisture; it is the } \\
\text { central hub of the } \\
\text { four regions, and the } \\
\text { meeting point of the } \\
\text { myriad things. }\end{array}$ \\
\hline
\end{tabular}


Fig. 5b (cont.)

\begin{tabular}{|c|c|c|c|c|c|}
\hline 5 Regions & East & West & North & South & Central \\
\hline $\begin{array}{c}2 . \\
\text { Customs }\end{array}$ & $\begin{array}{l}\text { The people here eat fish } \\
\text { and favor salty foods; } \\
\text { their benefits are } \\
\text { abundant, therefore } \\
\text { (all) are peaceful in their } \\
\text { abodes and therefore } \\
\text { they do as the please } \\
\text { [and] appreciate their } \\
\text { foods. }\end{array}$ & 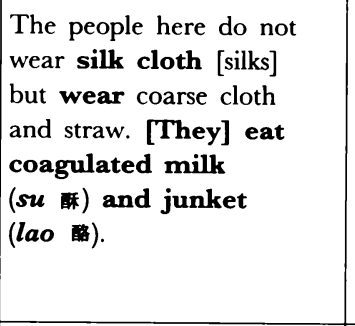 & $\begin{array}{l}\text { The people here like } \\
\text { to reside in the wild } \\
\text { and consume milk. }\end{array}$ & $\begin{array}{l}\text { The people here favor } \\
\text { sour [foods] and eat } \\
\text { fermented [foods]. } \\
\text { [They] do not use } \\
\text { incense. It is a } \\
\text { place where yang } \\
\text { dominates. }\end{array}$ & $\begin{array}{l}\text { Numerous, therefore } \\
\text { the people here eat } \\
\text { diverse [foods] and do } \\
\text { not get fatigued [i.e., } \\
\text { from hard work]. }\end{array}$ \\
\hline $\begin{array}{c}3 . \\
\text { Constitutions }\end{array}$ & $\begin{array}{l}\text { [Since] fish arise from } \\
\text { dampness and heat } \\
\text { they cause heat within } \\
\text { humans. The salt } \\
\text { enters the kidneys; } \\
\text { kidneys are classified } \\
\text { with Water, Water } \\
\text { governs Fire, Fire is } \\
\text { classified with the } \\
\text { heart, the heart rules } \\
\text { the Blood, [and] salt } \\
\text { rules over Blood, which } \\
\text { causes people to have } \\
\text { fevers and yin damage } \\
\text { [so] the people here all } \\
\text { have a dark complexion } \\
\text { and open [i.e., loosely } \\
\text { dispersed] pores. }\end{array}$ & $\begin{array}{l}\text { (The people here have } \\
\text { plentiful foods and) their } \\
\text { bodies are (thus) corpulent. } \\
\text { Skin and pores are } \\
\text { closed tightly, Blood } \\
\text { and } q i \text { are full, }\end{array}$ & & $\begin{array}{l}\text { Therefore (the people } \\
\text { here all have fine [i.e., } \\
\text { tightly dispersed] pores } \\
\text { and) many have a } \\
\text { reddish complexion.' The } \\
\text { sour sapor governs } \\
\text { restraint [i.e., } \\
\text { stringency], therefore } \\
\text { they all have fine } \\
\text { pores. Hot qi damages } \\
\text { the interior, damp qi } \\
\text { disperses on the } \\
\text { exterior, and with } \\
\text { theirpreference for } \\
\text { sour [foods], the liver } \\
\text { channel is harmed. }\end{array}$ & $\begin{array}{l}\text { The Major Essay on } \\
\text { the Resonance and } \\
\text { Appearance of Yin } \\
\text { and Yang [i.e., Inner } \\
\text { Ganon: Basic } \\
\text { Questions, \#5] said: } \\
\text { the damp qi of a } \\
\text { place, [if] contracted, } \\
\text { then harms the flesh } \\
\text { and tendons. }\end{array}$ \\
\hline
\end{tabular}


Fig. 5b (cont.)

\begin{tabular}{|c|c|c|c|c|c|}
\hline 5 Regions & East & West & North & South & Central \\
\hline $\begin{array}{c}4 . \\
\text { Illnesses }\end{array}$ & 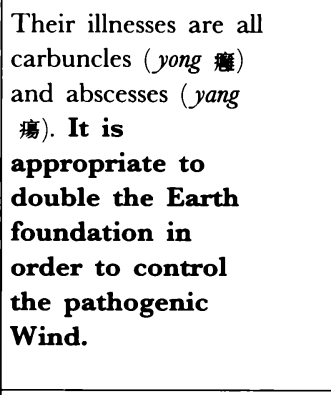 & $\begin{array}{l}\text { Therefore external } \\
\text { pathogenic }[q i] \text { cannot } \\
\text { harm (their bodies [so] } \\
\text { their illnesses arise } \\
\text { from within.), in all } \\
\text { cases their illnesses } \\
\text { arise from excesses } \\
\text { of the seven emotions, } \\
\text { consumption of food } \\
\text { and drink, and male- } \\
\text { female [relations]. }\end{array}$ & $\begin{array}{l}\text { The illnesses here are } \\
\text { mostly cold stroke; it } \\
\text { is appropriate to } \\
\text { increase the Fire } \\
\text { source in order to } \\
\text { diminish the concealed } \\
\text { yin (Hidden [pathogenic] } \\
\text { cold [in the body] gives } \\
\text { rise to illnesses of fullness } \\
\text { (manbing 满病).) }\end{array}$ & $\begin{array}{l}\text { Their illnesses are spasms } \\
\text { (luan 数) and numbness } \\
\text { in the trunk and limbs }(b i \\
\text { 瘦). It is appropriate } \\
\text { to take Water as the } \\
\text { ruler in order to } \\
\text { control the brilliance } \\
\text { of yang. }\end{array}$ & $\begin{array}{l}\text { Their illnesses are } \\
\text { often paralysis (wei 瘘), } \\
\text { numbness or coldness in } \\
\text { the extremities (jue 厥) } \\
\text { when qi has } \\
\text { retreated, and cold or } \\
\text { hot [disorders]. [One] } \\
\text { ought to assist Wood } \\
\text { as the ruler in order } \\
\text { to control the } \\
\text { pathogenic Earth. }\end{array}$ \\
\hline $\begin{array}{c}5 . \\
\text { Treatments }\end{array}$ & $\begin{array}{l}\text { Their appropriate } \\
\text { treatment is stone needles } \\
\text { (bianshi 砭石). }\end{array}$ & $\begin{array}{l}\text { Their appropriate } \\
\text { treatments are toxic [i.e., } \\
\text { potent] drugs (duyao 毒藥) } \\
\text { severe attack } \\
\text { [formulas], which can } \\
\text { also cause a quick } \\
\text { death. }\end{array}$ & $\begin{array}{l}\text { Their appropriate } \\
\text { treatment is moxibustion } \\
\text { and cauterization (jüuruo } \\
\text { 负炳). }\end{array}$ & $\begin{array}{l}\text { Their appropriate } \\
\text { treatment is needles } \\
\text { (zhen 鋮). }\end{array}$ & $\begin{array}{l}\text { Their appropriate } \\
\text { treatment is guiding- } \\
\text { pulling (daoyin } \\
\text { and massage (anqiao } \\
\text { 按踦). }\end{array}$ \\
\hline $\begin{array}{l}\text { 6. Origin of } \\
\text { Treatments }\end{array}$ & $\begin{array}{l}\text { This is why stone } \\
\text { needles also came } \\
\text { from the eastern } \\
\text { region. }\end{array}$ & $\begin{array}{l}\text { This is why toxic drugs } \\
\text { also came from the } \\
\text { western region. }\end{array}$ & $\begin{array}{l}\text { This is why moxibustion } \\
\text { and cauterization came } \\
\text { from the northern region. }\end{array}$ & $\begin{array}{l}\text { This is why the nine } \\
\text { needles came from the } \\
\text { southern region. }\end{array}$ & $\begin{array}{l}\text { This is why guiding- } \\
\text { pulling and massage } \\
\text { also came from the } \\
\text { central region. }\end{array}$ \\
\hline
\end{tabular}


Fig. 5b (cont.)

\begin{tabular}{|l|l|l|l|}
\hline 5 Regions & \multicolumn{1}{|c|}{ East } & \multicolumn{1}{|c|}{ West } & North \\
\hline Conclusion & $\begin{array}{l}\text { (Therefore, the sages combined the various [therapies] so as to treat each contracted [illness] according to what is appropriate [to it]. } \\
\text { Hence, as for cases of using different therapies and curing all the illnesses, this is because [they] grasped the circumstances of [each] } \\
\text { illness and understood the overall contours of therapy.) } \\
\text { Danxi said: The northwestern region has mostly wind and cold; therefore there are many of those who suffer from } \\
\text { external afflictions who live there. } \\
\text { [Li Zhongzi quoted the entire passage that Xu Chunfu attributed to Zhu Zhenheng and included in his Medical Compendium of } 1556, j u a n \\
\text { 3. Translated in full under section IV]. This is not far from the case when [one] is ignorant of the cause of surplus or } \\
\text { depletion, yet [one] wishes to exert oneself forcefully to draw up a plan of action. }\end{array}$
\end{tabular}

Fig. 5b. 'On locality \#15' (Fangtu lun di shizeu), juan 2,

On the Subtleties of Nourishing Life, Revised and Supplemented (Shan bu Yisheng weilun, pr. 1642 CE). 
did not here nor elsewhere give a clue to why he held such a negative view of westerners. Perhaps for him they represented people on the frontiers of China proper who were not integrated into the social expectations of moderation in Chinese culture. The drastic purgatives previously associated with the therapeutic style of the northern physician Zhang Congzheng became the regionally appropriate therapy for those who lived in the west where potent drugs were thought to have originated.

Li's comments on the appropriate responses to regional illnessesin the south, north, east, west, and centre-provided the general rationales of an herbal formula appropriate for each area. Li Zhongzi's revision of the Inner Canon's essay on regionalism not only interpolated the five phases into the Han original, it offered strategies for regionally appropriate herbal formulas that did not exist in the Former Han dynasty when the Inner Canon was compiled. ${ }^{89}$ This process of integrating herbal medicines into the five regions model appears to have begun with the same Zhang Congzheng whose drastic purgatives Li Zhongzi defended as appropriate for Zhang's poorer northern patients..$^{90}$

In the first essay of his famous Confucian's Serve Their Kin (Rumen shiqin 儒門事親), titled 'The rules of the seven formulas and the ten prescriptions' (qifang shiji shengmo 七方十劑繩墨), Zhang Congzheng listed the most appropriate drugs for each of the five regions. During the Jin dynasty, regional diversity in preferred drugs appears to have been so common that Zhang systematised them into the pre-existing five regions model from the Inner Canon:

As for the central region, its form is the Earth [phase] and so there are many cases of illnesses [there] of the spleen and stomach [i.e., because both are correlated to Earth]. The foods, dwellings, feelings, and longevity [of the centre] are shared in all four regions. As for using drugs, [they] also use miscellaneous [things] in their various formulas and [thereby] treat patients. For example, the east has Ceratophyllum demersum L. (zao 藻 $)^{91}$ and seaweed (dai 帶); $;^{92}$ the south has dingmu

89 On 'The pharmacology of systematic correspondence', see Unschuld 1985, 179-188.

${ }_{90}$ See Leung 2002, pp. 168-9; pp. 196-7 for this insight on Zhang Congzheng's innovation and examples of other doctors who specified certain drugs for different regions thereafter in the Ming and early Qing.

${ }_{91}$ Synonym is jin yu zao 金魚落 Ceratophyllum demersum L. (angl.--hornwort). Fèvre and Métailié 2005, p. 161.

${ }_{92}$ This term most likely refers to haidai 海带 Laminaria japonica Aresh. (angl.- 
丁木, ${ }^{93}$ the west has ginger (jiang 葨) 94 and aconite ( $f u$ 附);95 and the north has ginseng (shen 參) 96 and [the edible fungus] Poria cocos (ling 苓) $;{ }^{97}$ and the central region has Ephedra sinica (mahuang 麻黄).${ }^{98}$ [With] far reaching ambition [one] may possibly bring [the various regional drugs] together [into formulas, i.e., like spokes of a wheel] and participate in combining them [i.e., into new effective formulas] ${ }^{99}$

By the late-Ming dynasty, the considerable pharmaceutical literature including 'materia medica' (bencao 本草) and 'formularies' (fangshu 方書) had become the main therapeutic resources for literate physicians such as Li Zhongzi and his potential readers. Zhang Congzheng's comments on the drugs of the five regions influenced Li Zhongzi most clearly in his remarks on the need to control 'earth' (which corresponded to spleen and stomach illnesses) in the central region. Instead of Zhang's specific drugs, however, Li listed regionally appropriate therapeutic strategies for using drugs. Li did not elaborate at all on the other four therapeutic methods in the original Inner Canon essay - the stone needles of the east, the moxibustion and cauterisation of the north, the nine needles of the south, or the daoyin and massage practices of the centre. This omission suggests that these therapeutic techniques were of only antiquarian interest for an elite physician like himself whose practice consisted mainly of writing prescriptions. ${ }^{100} \mathrm{He}$ concluded his revision with the same quotation that

kombu). As materia medica, it could also refer to da ye zao 大葉藻 Zostera marina L. (angl.--eelgrass, grass wrack). Fèvre and Métailié 2005, pp. 91, 161.

${ }_{93}$ This term most likely refers to dingmushu 丁木樹, which has, however, two synonyms ciqiu 刺权 Kalopanax septemlobus (Thunb.) Koidz [= Kalopanax pictus (Thunb.) Nakai] and liangzimu 椋子木 Cormus macrophylla Wall. (angl.--largeleaf dogwood). Fèvre and Métailié 2005, pp. 69, 106, 275.

${ }_{94}$ Fresh form is shengïang 生䓰, dried form ganjiang 乾董, Zingiber officianale Rosc. (angl.- ginger). Fèvre and Métailié 2005, p. 228; Hu 1980, p. 10.

${ }_{95}$ Full term is fuzi 附子 Aconitum carmichaelii Debx. (angl-Sichuan Aconite, or monkshood). Synonyms wutou 烏頭 and jitouzi 雞頭子. Fèvre and Métailié 2005, pp. 139, 473; Hu 1980, p. 32.

${ }_{96}$ Full term is renshen 人參 Panax ginseng C.A. Mey. [= Panax schinseng Nees] (angl.ginseng). Fèvre and Métailié 2005, p. 373; Hu 1980, p. 49.

97 Full term is fuling 获苓 Poria cocos (Schw.) Wolf. (angl.--Tuckahoe, Indian bread, Virginia truffle). Fèvre and Métailié 2005, p. 138; Hu 1980, p. 31.

${ }_{98}$ Fèvre and Métailié 2005, p. 300; Hu 1980, p. 67.

${ }^{99}$ Rumen shiqin, juan 1, p. 21.

100 For support of this argument that mid- to late-Ming physicians preferred drugs over acupuncture and moxibustion, see Furth on the pharmaceutical strategies of the Ming doctor Cheng Congzhou (1581-?), 1999, pp. 224-65. See also Cullen on literate male practitioners and their preference for drug therapies in his analysis of the medical care in the 16th-century novel finpingmei, 1993, pp. 115-22. 
Xu Chunfu quoted and attributed to Zhu Zhenheng on 'The four regions wind and soil not being the same'. By quoting Zhu on the 'four regions', Li related the ancient five regions model to the northwestsoutheast polarity with which most of his readers would already be familiar. This northwest-southeast polarity not only mirrored a geographic and social reality for physicians, it was for them a medical fact that guided their choice of therapies and structured their assessments of a skewed physical and human geography.

\section{Conclusion}

The Ming medical discourse on regional diseases revealed three types of social diagnosis: 1) conflicts over diverse practices in the literate sector of medicine, 2) concerns about universal validity over regional biases, and 3) anxieties about the health consequences of the increasingly indulgent lifestyles in the wealthy regions to the southeast. The greater value placed on all things associated with the northwest and the north can be traced back to their historical place as the political and cultural centres of Chinese culture. These geographic divisions were also more important in Chinese medical discourse than the urban-rural divide that dominated European medical discourse because of China's political history going back to the north-south division of the Northern Jin and Southern Song dynasties. ${ }^{101}$

These geographic divisions also reveal actual social fissures in the medical sphere that were regionally based. The northern officialscholar Dai Liang made the northern-southern conflict visible in his biography of the Jiangnan physician Xiang Xin and in his preface for the Suzhou physician Zhu Bishan. Just over a century later in the first decade of the sixteenth century, Wang Lun, by contrast, challenged critics who sought to diminish Zhu Zhenheng's work as merely southern. He also warned his novice readership to avoid simplistic environmental determinism and to become more discerning in their practice. During the mid-sixteenth century Xue Ji, on the other hand, emphasised corporeal differences and expressed concern about the regional limits of drug therapies for epidemics. Xue Ji's emphasis on regional constitutionalism contrasted markedly with Wang Lun's critique of regional essentialism. Near the end of the

${ }^{101}$ Summary of arguments in Leung 2002, pp. 201-3. 
Ming in the 1620s, by contrast, Li Zhongzi explained Zhang Congzheng's use of 'northern purgatives' and Xue Ji's own bias toward 'southern restoratives' as rooted in the economic differences between the north and the south.

The commercial transformation of Chinese society between the time of Xue Ji in the 1550s and Li Zhongzi in the 1620s, increased the chasm between the rich and poor to such an extent that economic status became a newly resonant maker of even corporeal difference. Furthermore, Li's updating of the Inner Canon: Basic Question's 'Different methods being regionally appropriate', added the five phases doctrine and herbal medicine strategies that had been integrated into the Chinese formulary literature since the innovations in drug therapy of the Jin-Yuan period. ${ }^{102}$ Sympathetic with Wang Lun's arguments for impartiality, however, Li Zhongzi also cautioned physicians against regional determinism. The ideal persona of an unbiased and impartial elite physician emerged from this medical debate on 'northern purgatives and southern restoratives' as a compelling (if not new) social identity for Ming literati physicians and a persuasive marketing strategy in the publishing realm. Although the debate clearly expressed nostalgia for the frugality, restraint, and hardiness associated with the northwest, their portrayal of the more leisurely, indulgent, and delicate southern patient could also be read as an affirmation of southern cultural distinctiveness, if not actual superiority. These southern medical authors presented their own syntheses of medical knowledge as balanced, comprehensive, and universal.

A synchronic approach to Ming medical regionalism uncovered a wide range of sixteenth-century sources that used the geo-climatic northwest-southeast polarity in multiple ways. The illustrations in the Yuan and Ming editions of the Broad-Ranging Record on Many Matters encyclopaedia depicted the world askew since the time Gong Gong knocked down the north-western pillar Mount Buzhou holding up heaven. Ming physicians used the northwest-southeast polarity in their writings on medical diversity because at that time it was a widely held 'social fact' that corresponded not only with their sense of political history, but also with their social and medical experience. The Ming medical debate over northern purgatives and southern

102 Unschuld 1985, 179-188. A comparable integration of Jin-Yuan innovations in materia medica and herbal formularies can be seen in the work of his disciple Guo Peilan 郭佩萰 for whose Collected materia medica (Bencao hui 本草滙) Li Zhongzi wrote a preface. Unschuld 1986, 120-22. 
restoratives occurred within this symbolic system. From the perspective of the sociology of knowledge, it was also fundamentally about southern physicians - such as the official-physician Wang Lun, the southern physician Xue Ji, the medical compiler Xu Chunfu, and the scholar-physician Li Zhongzi-strategically carving out a new social niche for themselves as the impartial medical authorities for all citizens of the Ming empire in all their diversity, north and south, noble and ignoble.

\section{Acknowledgements}

I would like to thank the following people and institutions for inviting me to present earlier versions of this article. Ruth Rogaski and TJ Hinrichs organised a Chinese medical text reading workshop at Princeton University in the spring of 2000, which gave me the opportunity to first discuss with other scholars my initial interpretations of Wang Lun's Enlightened Physicians. Professors Liu Dun 劉鈍 and Cheng Chen-yi 程真-invited me to present the earliest version of this article at the Ninth International Meeting of the History of Chinese Science, Hong Kong University, 9-12 October 2001. I also learned from many colleagues when I presented this research for a panel I chaired on 'Cultural Authority in Chinese Medical History' at the Tenth International Conference of the History of East Asian Science, Technology, and Science Society, Shanghai Communications University, 20-23 August 2002. I would also like to thank Professor Hsiung Ping-chen 熊秉真 who invited me to present an earlier version of this research at the Modern History Institute of Academia Sinica, 23 September 2002. Finally, I am grateful to Professor Li Jianmin 李建民 for inviting me to the conference on 'Medical Perspectives on Chinese History', 13-15 December 2005. I completed this revision in large part because of his encouragement, support, and especially patience. I would also like to thank the first two anonymous reviewers who gave me sound criticism and Ms. Beatrice Yang who translated it into Chinese for Li Jianmin's edited volume, Cong yiliao kan zhongguo shi 從醫療看中國史 (Medical Perspectives on Chinese History). Two reviewers from Asian Medicine offered further suggestions and insightful criticisms, which I have integrated as much as possible into this final and shorter English version. Michael Helme invented the Chinese footnotes into the AM format for footnotes and references, improving the manuscript in the process. Vivienne Lo deserves a 
final accolade for her editorial magic wand. All remaining problems and errors remain my own.

\section{References}

The following abbreviation LHML \# indicates the titles and editions of medical texts according to Xue Qinglu, et al. (eds.) 1991, Quanguo Zhongyi tushu lianhe mulu.

\section{Primary sources}

Danxi yï 丹溪整集 (Collected Medical Works of Danxi), Zhu Zhenheng 朱震亨 (12821358), Reprint-Beijing: Renmin weisheng chubanshe, 1995.

Gujin luli kao 古今律歷考 (Examination of the Calendar, Past and Present), Xing Yunlu 邢雲路, jinshi 1580, Zhang Yining 張以寀, 1301-1370, electronic edition of the Wenyuange Siku quanshu, Reprint-Shanghai: Shanghai guji chubanshe, 1987.

Gujin yitong daquan 古今醫統大全 (Compendium of the Medical Tradition, Past and Present), Xu Chunfu 徐春甫, completed 1556, LHML \#11510, Reprint-Cui Zhongping 崔仲乎Wang Yaoting 王耀輝廷 (eds.), Beijing, Renmin weisheng chubanshe, 1998.

Huainanzi 淮南子, in Sibu beiyao 四部備要 (Essentials of the Four Branches of Literature), Reprint - Shanghai: Zhonghua shuju, 1990 [1935].

Huangdi neijing: suwen \& lingshu 黃帝內經: 素問, 覀樞 (Inner Canon of the Yellow Emperor: Basic Questions \& Divine Pivot), Reprint-Ren Yingqiu 任應秋 1986 [1960], Huangdi neijing zhangju suoyin 黃帝内經章句索引 (Phrase Index to the Inner Canon of the Yellow Emperor), Beijing: Beijing renmin weisheng chubanshe.

Jiuling shanfang $\ddot{i}$ 九㶾山房集 (Collected Works from the Mountain Villa of Nine Divinities), Dai Liang 戴良 (1317-1383), electronic edition of the Wenyuange Siku quanshu, Reprint - Sibu congkan, Shanghai: Shanghai yinshu guan, 1927. Also ReprintShanghai guji chubanshe, 1987.

Lei jing 類經 (Classified Canon), by Zhang Jiebin 張介賓, this version published in 1624 by Finchang tong yong quan 金間童涌泉, LHML \#00033.3, Reprint--Li Zhiyong (ed.), Zhang Jingyue yixue quanshu, Beijing: Zhongguo zhongyiyao chubanshe, 1999.

Lei jing tuyi 類經圖翼 (Illustrated Commentary of the Classified Canon), Zhang Jiebin 張介賓, this version published in 1624 as an appendix to the Leijing by Finchang tong yong quan 金閵童涌泉, LHML \#00033.3, Reprint一Li Zhiyong (ed.), Zhang Jingyue yixue quanshu, Beijing: Zhongguo zhongyiyao chubanshe, 1999.

Mingyi zazhu 明醫雜著 (Miscellaneous Writings by Enlightened Physicians), Wang Lun 王綸, $1502 \mathrm{CE}$ completed, this version commentated on and reprinted by Xue $\mathrm{Ji}$ in 1549 CE, LHML \#04903.2, Reprint-Wang Xinhua 王新 華 (ed.), Zhongyi guji xiaocongshu, Nanjing: Jiangsu kexue jishu chubanshe, 1985.

Mingyi zhizhang 明醫指掌 (Guide for Enlightened Physicians), by Huang Fuzhong 皇甫中, earliest edition $1579 \mathrm{CE}$, this version edited by Wang Kentang in 1622 CE, LHML \#04916.2, Reprint-Zhang Yinsheng 張印生 (ed.), Ming Qing zhongyi linzheng xiaocongshu, Beijing: Zhongguo zhongyiyao chubanshe, 1997.

Puji fang 普済方 (Formulas for General Benefit), Zhu Su 朱㙌 (d. 1425), completed 1390, earliest extant edition 1618, LHML \#02995.1, in electronic edition of the Wenyuange Siku quanshu, Reprint-Taipei, Shangwu,1982; Beijing: Renmin weisheng chubanshe, 1958-1960.

Rumen shiqin 儒門事親 (Confucians Serve Their Kin), Zhang Congzheng 張從正, LHML \# 14879, Reprint-Deng Tietao 鄧鐵漙 (ed.), Zihe yiji 子和醫集 (Zihe's Collected Writings on Medicine), Beijing: Renmin weisheng chubanshe, 1996. 
Sheng shou wannian li 聖尋萬年歷 (Imperial Longevity Permanent Calendar), edited by Zhu Zaiyu 朱載䏴, 1536-1611, in electronic edition of the Wenyuange Siku quanshu, Reprint-Taipei, Shangwu yinshuguan, 1981; Shanghai guji chubanshe, 1987.

[Xinbian qunshu leiyao] Shilin guangï [新編群書類要] 事林廣記 (Broad-Ranging Record on Many Matters), by Chen Yuanjing 陳元靚 Japanese Zhishun (ed.) 1699, Reprint-Beijing: Zhonghua shuju chuban, 1999.

[Zuantu zengxin leiju] Shilin guangji [集圖增新類聚] 事林廣記 (Broad-Ranging Record on Many Matters), by Chen Yuanliang 陳元靚, Xiyuan jingshe 西園精舎 reprint, Ming Hongzhi edition (r. 1488-1505), Reprint-Taipei facsimile. Fu Sinian library, Academia Sinica.

[Zuantu zengxin qunshu lei yao] Shilin guangï [等圖增新群書類要] 事林廣記 (BroadRanging Record on Many Matters), by Chen Yuanliang 陳元靚, Jian an chunzhuang shuyuan 建安椿莊書院 Yuan Zhishun edition (r. 1330-33), Reprint-Beijing, Zhonghua shuju chuban, 1999.

Su Shen liangfang 蘇沈良方 (The Superlative Formulas of Su (Shi) and Shen (Kuo)), by Su Shi 蘇軾, 1036-1101, Shen Kuo 沈括, 1031-1095, Dong J董汲. fl. 1078-1093, preface 1075, earliest extant edition Jiaqing reign (1522-1566) LHML \#02940.1, in electronic edition of the Wenyuange Siku quanshu, Reprint-Beijing : Zhong hua shu ju, 1985 [1935].

Wenyuange Siku quanshu electronic edition 文淵閣四庫全書電子版 [1782], Zhongwen daxue chubanshe 中文大學出版社.

Wusao hebian 吳騷合編 (Combined Compilation of Sao (poems) of Wu (region)), edited and compiled by Zhang Qi 張琦 (late 16th-early 17th century), facsimile of the Ming Chongzhen edition (1628-1644), Reprint-Taibei: Shangwu chubanshe, 1966.

Xueshi yi'an ershisi zhong 薛氏醫案二十四種 (Mr Xue's Medical Case Histories, 24 Kinds), Wanli blockprint (r. 1628-1644), LHML \#11573.1; and Xuezhi yi'an shiliu zhong 薛氏醫案十六種 (Mr Xue's Medical Case Histories, 16 Kinds), 1628 blockprint, LHML \#11574.1.

[Shan bu] Yisheng weilun [删補 頋生薇論 (On the Subtleties of Nourishing Life, Revised and Supplemented), Li Zhongzi 李中梓 completed 1618, reprinted in 1642, LHML \#11520.2, Reprint-Bao Laifa (ed.), Li Zhongzi yixue quanshu, Beijing: Zhongguo zhongyiyao chubanshe, 1999.

rizong bidu 醫宗必讀 (Required Readings for Physicians (of the Orthodox) Lineage), Li Zhongzi 李中梓, printed in 1637, LHML \#11519.1, Reprint-Bao Laifa (ed.), Li Zhongzi yixue quanshu, Beijing: Zhongguo zhongyiyao chubanshe, 1999.

Yuanqu xuan 元曲選 (Selected Yuan Dynasty Verses), Zang Maoxun 藏惁循, flourished c. 1553-c. 1621, 4 volumes, Reprint-Taibei: Zhonghua shuju, 1966.

Secondary sources

Allan, S. 1991, The Shape of the Turtle: Myth, art, and cosmos in early China, Albany: SUNY.

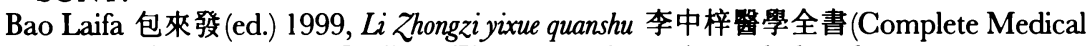
Works of Li Zhongzi), Beijing: Zhongguo zhongyiyao chubanshe.

Barrett, T. H. 1993, 'Lieh tzu' 列子, in M. Loewe (ed.), Early Chinese Texts: A Bibliographical Guide, Berkeley: The Society for the Study of Early China and The Institute of East Asian Studies, University of California, 298-308.

Birrell, A. 1993, Chinese Mythology: An introduction, Baltimore/London: The Johns Hopkins University Press.

Brokaw, C. J. and Kai-wing Chow (eds.) 2005, Printing and Book Culture in Late Imperial China, Berkeley: University of California Press.

Cheng Weizhong 盛維忠 (ed.) 1999, Xue Lizhai yixue quanshu 薛立齋醫學全書 (The Complete Medical Works of Xue Lizhai (Xue Ji 薛己)), Beijing: Zhongguo zhongyiyao chubanshe. 
Cullen, C. 1993, 'Patients and Healers in Late Imperial China: Evidence from the Jinpingme', History of Science, 31: 99-150.

Despeux, C. 2005, 'Visual Representations of the Body in Chinese Medical and Daoist Texts from the Song to the Qing Period (Tenth to Nineteenth Century', Asian Medicine 1.1: 10-52.

Douglas, M. 1982 [1973], Natural Symbols: Explorations in Cosmology, New York: Pantheon Books.

Eyler, J. M. 1992, 'The Sick Poor and the State: Arthur Newsholme on poverty, disease, and responsibility', in C. E. Rosenberg and J. Golden (eds.), Framing Disease, New Brunswick, NJ: Rutgers University Press, 275-96.

Fan Ka Wai 范家偉 1995, 'Dong Jin zhi Song dai jiaoqibing zhi tantao' 東晉至宋 代腳氣病之探討 (Discussion of Beriberi from Eastern Song to Jin Dynasty), Xin shi xue, 6.1: 155-77.

- 2004, Liu Chao Sui Tang yixue zhi chuancheng yu zhenghe 六朝隋唐警學之傳承與 整合 (Transmission and Integration of Chinese Medicine from the Six Dynasties through the Tang Dynasty), Hong Kong: Chinese University of Hong Kong.

Fee, E. 1992, 'Henry E. Sigerist: His interpretations of the history of disease and the future of medicine', in C. E. Rosenberg and J. Golden (eds.), Framing Disease, New Brunswick, NJ: Rutgers University Press, 297-317.

Feher, M. with R. Naddaf and N. Tazi (eds.) 1989, Fragments for a History of the Human Body, Part Three, New York: Zone Books.

Feng Huimin 馮惠民 and Li Wanjian 李萬健 1994, Mingdai shumu tiba congkan 明代書目題跋叢刊 (Prefaces, Postscripts, (and Titles) in Ming Dynasty Book Catalogues), 2 vols, Beijing: Shumu wenxian chubanshe.

Fèvre, F. and G. Métailié 2005, Dictionnaire RICCI des plantes de Chine: chinois-franģais, latin, anglais, Paris: Association Ricci-Les Éditions du Cerf.

Field, S. trans. 1986, Tian Wen: A Chinese Book of Origins, New York: New Directions.

Furth, C. 1999, A Flourishing Yin: Gender in China's Medical History, 960-1665, Berkeley: University of California Press.

Goldschmidt, Asaf 2005, 'The Song Discontinuity: Rapid Innovation in Northern Song Dynasty Medicine,' Asian Medicine 1.1: 53-90.

- 2006, 'Huizong's Impact on Medicine and Public Health', in P. Ebrey and M. Bickford (eds.), Emperor Huizong and Late Northern Song China; the politics of culture and the culture of politics, Cambridge, Mass.: Harvard University Press.

Graham, A. C. 1990, The Book of Lieh-tzŭ: A classic of Tao, New York: Columbia University Press.

Grant, J. 2003, A Chinese Physician: Wang Fi and the 'Stone Mountain Medical Case Histories', London: RoutledgeCurzon.

Hanson, M. 1997, "Inventing a Tradition in Chinese Medicine: From Universal Canon to Local Medical Knowledge in South China, The Seventeenth to the Nineteenth Century," University of Pennsylvania, PhD Thesis.

— 1998, "Robust Northerners and Delicate Southerners: The Nineteenth-Century Invention of a Southern Wenbing Tradition," in special issue "Empires and Hygiene" of Positions: East Asia Cultures Critique 6.3: 515-49. Revised for E. Hsu (ed.) 2001, Innovation in Chinese Medicine, Cambridge: Cambridge University Press, 262-92.

Hawkes, D. 1985, The Songs of the South: An ancient Chinese anthology of poems by $Q u$ Yuan and Other Poets, London: Penguin Books.

- 1993, 'Ch'u tz'u' 楚辭, in M. Loewe (ed.), Early Chinese Texts: A Bibliographical Guide, Berkeley: The Society for the Study of Early China and The Institute of East Asian Studies, University of California, 48-55.

He Shixi 何時希 1991, Zhongguo lidai yijia zhuan lu 中國歷代醫家傳錄 (Record of the Biographies of Chinese Physicians Throughout History), 3 volumes, Beijing: Renmin weisheng chubanshe. 
Hinrichs, TJ 2004 "The Medical Transforming of Governance and Southern Customs in Song Dynasty China (960-1279 C.E.)." Ph.D. diss., Harvard University.

$\mathrm{Hu}$ Shiu-ying, with editorial assistance of Y.C. Yong and Paul P.H. But 1980, An Enumeration of Chinese Materia Medica, Hong Kong: The Chinese University Press.

Kleinman, A. 1980, Patients and Healers in the Context of Culture, an exploration of the borderland between anthropology, medicine and psychiatry, Berkeley: University of California Press.

Le Blanc, C. 1993, 'Huainanzi' 淮南子, in Loewe M. (ed.), Early Chinese Texts: A Bibliographical Guide, Berkeley: The Society for the Study of Early China and The Institute of East Asian Studies, University of California, 189-95.

Leung, A. K-C. (published under Chinese name 梁其姿) 2002, 'Jibing yu fangtu zhi guanxi: Yuan zhi Qing jian yijie de kanfa' 疾病與風土之關係: 元至清間㹂界的看法 (The Relationship Between Illness and the Environment: Perspectives on the Medical World from the Yuan to the Ming), in Huang Kewu 黄克武 (ed.), 'Xingbie yu yiliao': disan jie guoii hanxue huiyi lunwenji 性別與醫療: 第三屆國 際漢學會議論文集 (Gender and Medical History: Papers from the Third International Conference on Sinology), Taibei: Zhongyang yanjiuyuan, jishisuo, 165-212.

Leung, A. K-C. 2003a, 'Medical Learning from the Song to the Ming', in R. von Glahn and P. Jakov Smith (eds.), The Song-Yuan-Ming Transition in Chinese History, Cambridge, MA: Harvard University Asia Center, 374-98.

2003b, 'Medical Instruction and Popularization in Ming-Qing China', Late Imperial China, 24.1: 130-52.

Li Yun 李雲 (ed.) 1988, Zhongyi renming cidian 中㹂人名辭典 (Biographical Dictionary of Chinese Physicians), Beijing: Guoji wenhua chubanshe gongsi.

Li Zhiyong 李志庸 (ed.) 1999, Zhang Jingyue yixue quanshu 張景岳醫學全書 (The Complete Medical Works of Zhang Jingyue (Zhang Jiebin 張介寉)), Beijing: Zhongguo zhongyiyao chubanshe.

Loewe, M. (ed.) 1993, Early Chinese Texts: A Bibliographical Guide, Berkeley: The Society for the Study of Early China and The Institute of East Asian Studies, University of California.

Lu Gwei-djen, and J. Needham 1980, Celestial Lancets: A History $\mathcal{E}$ Rational of Acupuncture \& Moxa, Cambridge: Cambridge University Press.

Major, J. S. 1993, Heaven and Earth in Early Han Thought : Chapters three, four and five of the Huainanzi, with appendix by C. Cullen, Albany: State University of New York Press.

Needham, J. 2000, 'Medicine in Chinese culture', Science and Civilization in China, Volume VI: 6, edited with an introduction by Nathan Sivin, Cambridge: Cambridge University Press, 38-66.

Pelling, M. 1996, 'Compromised by Gender: The role of the male medical practitioner in early modern England', in H. Marland and M. Pelling (eds.), The Task of Healing: Medicine, Religion and Gender in England and the Netherlands, 1450-1800, Rotterdam: Erasmus Publishing, 101-33.

Ren Yingqiu 任應秋 1986 [1960], Huangdi neijing zhangju 黃帝内經章句索 引 (Phrase Index to the Inner Canon of the Yellow Emperor), Beijing: Beijing renmin weisheng chubanshe.

Rosenberg, C. E. 1962, The Cholera Years: The United States in 1832, 1849, and 1866, Chicago: University of Chicago Press.

- 1992a, 'Cholera in Nineteenth-century Europe: A tool for social and economic analysis', Explaining Epidemics and Other Studies in the History of Medicine, Cambridge, England: Cambridge University Press, 109-21.

- 1992b, 'Framing Disease: Illness, society, and history', in C. E. Rosenberg and J. Golden (eds.), Framing Disease: Studies in Cultural History, New Brunswick, NJ: Rutgers University Press, xiii-xxvi. 
Rosenberg, C. E. and J, Golden (eds.) 1992, Framing Disease: Studies in Cultural History, New Brunswick, NJ: Rutgers University Press.

Rupke, N. (ed.) 2000, Medical Geography in Historical Perspective, Medical History, Supplement No. 20, London: The Wellcome Trust Centre for the History of Medicine at University College London.

Schatzki, T. R. and W. Natter 1996, 'Sociocultural Bodies, Bodies Sociopolitical', in T. R. Schatzki and W. Natter (eds.), The Social and Political Body, New York: The Guilford Press, 1-25.

Sivin, N. 1993, 'Huang ti nei ching' 黃帝内經, in M. Loewe (ed.), Early Chinese Texts: A Bibliographical Guide, Berkeley: The Society for the Study of Early China and The Institute of East Asian Studies, University of California, 196-215.

- 1995a, 'State, Cosmos, and Body in the Last Three Centuries BC', Harvard Journal of Asiatic Studies, 55.1: 5-37.

- 1995b, 'Text and Experience in Classical Chinese Medicine', in D. Bates (ed.), Knowledge and the Scholarly Medical Traditions, Cambridge: Cambridge University Press, 177-204.

Sun Tiansheng 孫天勝 1994, 'Chuantong yixuezhong de yixue dili sixiang yanjiu' 傳統醫學中的整學地理思想研究 (A Study of Medico-geographical Thought in Traditional Chinese Medicine), Renwen dili 人文地理 (Human Geography), 9.3: 68-74.

Unschuld, P. 1985, Medicine in China: A History of Ideas, Berkeley: University of California Press.

1986, Medicine in China: A History of Pharmaceutics, Berkeley: University of California Press.

Unschuld, P. trans. 1990, Forgotten Traditions of Ancient Chinese Medicine: A Chinese View from the Eighteenth Century, The I-hsüeh yüan liu lun of 1757 by Hsü Ta-Ch'un, Brookline, Mass.: Paradigm Publications.

Widmer, E. 1996, 'The Huanduzhai of Hangzhou and Suzhou: A study in seventeenth-century publishing', Harvard Journal of Asiatic Studies, 56.1: 77-122.

Wu Yiyi 1993-4, 'A Medical Line of Many Masters: A prosopographical study of Liu Wansu and his disciples from the Jin to the Early Ming', Chinese Science, 11: 60 .

Xiao Fan 蕭璠 1993, 'Han Song jä wenxian suojian gudai zhongguo nanfang de dili huanjing yu difang bing ji qi yingxiang' 漢宋間文獻所見古代中國南方的地理 環境與地方病及 其影響 (Perspectives from Han to Song Sources on the Environments and Local Diseases of Ancient Southern China and Their Influence), Zhongyang yanjiuyuan lishi yuyan yanjiusuo jikan 中央研究院歷史語 言研究所集刊, 63.1: 67-171.

Xu Senyu 徐森玉 (ed.) 1986, Zhongguo congshu zonglu 中國丵書綜錄 (Catalogue of Chinese Collectanea), Shanghai: Shanghai guji chubanshe.

Xue Qinglu 薛清綠, et al. (eds.) 1991, Quanguo zhongyi tushu lianhe mulu 全國中 醫圖 書聯合目錄 (Union Catalogue of Books on Chinese Medicine), Beijing: Zhongyi guji chubanshe. Abbr. LHML.

Zimmerman, F. 1987 [1982], The Jungle and the Aroma of Meats: An ecological theme in Hindu medicine, trans. J. Lloyd, Comparative Studies of Health Systems and Medical Care series, Berkeley: University of California Press. Originally published as $L a$ jungle et le fumet des viands, Paris: Editions du Seuil. 